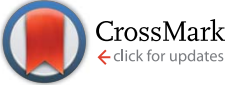

Cite this: RSC Adv., 2017, 7, 7801

Received 2nd December 2016 Accepted 13th January 2017

DOI: 10.1039/c6ra27671g

www.rsc.org/advances

\section{Mesoporous cerium-zirconium oxides modified with gold and copper - synthesis, characterization and performance in selective oxidation of glycerol $\dagger$}

\begin{abstract}
Piotr Kaminski, ${ }^{* a b}$ Maria Ziolek ${ }^{a}$ and Jeroen A. van Bokhoven ${ }^{\text {bc }}$
The main goal of this work was the synthesis of mesoporous ceria, zirconia and cerium-zirconium oxides, the application of these supports for the preparation of monometallic (copper or gold) and bimetallic (copper and gold) catalysts and characterisation of their performance in the oxidation of glycerol in basic aqueous solution in the presence of oxygen. The methods applied for the study included: adsorption/ desorption of nitrogen, XRD, ICP-OES, XPS, UV-vis, STEM-EDXS, $\mathrm{H}_{2}$-TPR. The presence of the following species $\mathrm{Au}^{0}, \mathrm{Au}^{\delta+}$, negatively charged gold $\mathrm{Au}^{-}$or $\mathrm{Au}^{0}$ in bimetallic particles, $\mathrm{Cu}^{+}, \mathrm{Cu}^{2+}, \mathrm{Ce}^{3+}$ and $\mathrm{Ce}^{4+}$, $\mathrm{Zr}^{4+}$ was confirmed and their content was found to depend on the catalyst composition. The interaction between gold and copper species in bimetallic samples caused the formation of the negative charge on gold and the increase of the amount of $\mathrm{Cu}^{+}$cations on the catalyst surface. This feature and the higher gold dispersion gave rise to a significant increase in the catalytic activity in glycerol oxidation of bimetallic catalysts with respect to that of monometallic samples. The high selectivity to glyceric acid (GLA) is an important advantage of the bimetallic catalysts (copper-gold), especially those loaded on mixed cerium-zirconium oxides. The bimetallic catalysts were stable and in the second run of the reaction they almost did not change glycerol conversion and increased the selectivity to GLA. The texture parameters of the catalysts had also impact on the selectivity of the reaction: the lower the microporosity the higher the selectivity to GLA. The role of the support is the interaction with copper and gold active species and enhancement of the reagents' chemisorption and electron transfers.
\end{abstract}

\section{Introduction}

Bimetallic catalysts supported on metal oxides receive much interest. Bimetallic catalysts containing gold are attractive in different catalytic oxidation processes, e.g. oxidation of carbon monoxide, ${ }^{1-7}$ methanol, ${ }^{8-11}$ and other alcohols. ${ }^{12-18}$ In the case of gold catalysts, metallic gold on the surface of catalysts promotes oxidative properties by leading to higher mobility of oxygen and to a much easier reduction of the copper species. ${ }^{19}$ The transfer of electrons is difficult on a metallic gold surface; however, copper has a greater electron-donating ability and it can modify the electronic and structural properties of gold. ${ }^{20}$ Catalysts containing gold that is modified with copper can be useful for the simultaneous total oxidation of carbon monoxide and methanol from gases emitted by automotive devices and during

${ }^{a}$ Adam Mickiewicz University in Poznań, Faculty of Chemistry, ul. Umultowska 89b, 61-614 Poznań, Poland.E-mail: piotr.kaminski@amu.edu.pl

${ }^{b}$ ETH Zürich, Institute for Chemical and Bioengineering, Vladimir-Prelog-Weg 1, CH8093 Zürich, Switzerland

${ }^{c}$ Paul Scherrer Institute, Laboratory for Catalysis and Sustainable Chemistry, CH-5232 Villigen, Switzerland

$\dagger$ Electronic supplementary information (ESI) available. See DOI: 10.1039/c6ra27671g industrial processes. ${ }^{11,21,22}$ The bimetallic copper-gold catalysts promoted with ceria and/or zirconia loaded on mesoporous SBA-15 materials exhibited higher activity in methanol oxidation than analogues monometallic gold or copper catalysts. ${ }^{\mathbf{1 1}}$ The chemical composition and structure of the support used for gold-copper play an important role in the activation of bimetallic particles. Recently, it was shown that gold-copper loaded on ceria, zirconia and mixed ceria-zirconia supports have changed electronic state of gold and that the mobility of oxygen from the support plays an important role in methanol oxidation. ${ }^{23}$ The activation of the catalysts at higher temperature, which is necessary for oxidation of methanol, strongly affected the surface properties and activity and selectivity in this reaction.

The idea of this work is to apply mesoporous ceria-zirconia mixed oxides with different chemical composition as support for the copper-gold active phase and to investigate the role of chemical composition and structure on the catalytic performance in the liquid phase glycerol oxidation. Ceria-zirconia supports are widely applied in exhaust-gas purification, ${ }^{\mathbf{2 4 , 2 5}}$ but they are not often used for fine chemical catalytic syntheses. The addition of zirconia to pure ceria improves not only the resistance against sintering at a high temperature compared to pure ceria, ${ }^{25,26}$ but it also affects the oxygen storage capacity. ${ }^{25}$ This 
may be very attractive for the interaction with copper-gold phases and for their application in oxidation processes. In contrast to the earlier study, ${ }^{23}$ in this work the catalysts are not activated at higher temperature before the catalytic oxidation of glycerol. Glycerol oxidation over gold catalysts on different supports has been studied by many authors over the last 15 years. ${ }^{27-35}$ We analyzed the synergistic effect between copper and gold as well as the influence of the supports.

\section{Experimental}

\subsection{Preparation of catalysts}

2.1.1. Synthesis of zirconia. Zirconia was synthesized by the hydrothermal method using a surfactant as a structure directing agent. $^{36-39}$ A micellar solution of cetyltrimethylammonium bromide (CTMABr, Sigma-Aldrich) was prepared by dissolving the surfactant at room temperature for $3 \mathrm{~h}$ in an aqueous acidic solution ( $\mathrm{pH}=2$ controlled by $35-38 \%$ $\mathrm{HCl}$, Chempur). Zirconium $n$-tetrapropanol $\left(\mathrm{Zr}\left(\mathrm{OC}_{3} \mathrm{H}_{7}\right)_{4}, 70 \%\right.$ in 1-propanol, Fluka) was added dropwise to the solution of the surfactant to reach the surfactant/precursor molar ratio of 0.33 . The gel obtained after stirring for $1 \mathrm{~h}$ at $313 \mathrm{~K}$ was sealed into a polypropylene bottle and heated for $24 \mathrm{~h}$ at $353 \mathrm{~K}$. The template was removed by extraction in Soxhlet apparatus at 351 $\mathrm{K}$ using ethanol for $30 \mathrm{~h}$. Then, the oxide was dried in a vacuum rotator at $343 \mathrm{~K}(200-300 \mathrm{mbar})$ and calcined at $673 \mathrm{~K}$ for $4 \mathrm{~h}$ with a heating rate of $3 \mathrm{~K} \mathrm{~min}^{-1}$. The calcination was used to remove the organic template and other carbonates, which are present after drying.

2.1.2. Preparation of mixed cerium-zirconium oxides, $\mathrm{CeZrO}_{x}$ (molar ratio of $\mathrm{Ce}: \mathrm{Zr}=1: 2$ and $1: 1$ ). The mixed oxides to be studied were synthesized according to the literature methods. ${ }^{36-39} \mathrm{CeZrO}_{x}$ were prepared using an aqueous acidic solution ( $\mathrm{pH}=2$ controlled by $35-38 \% \mathrm{HCl}$, Chempur) of 15 wt\% cetyltrimethylammonium bromide (CTMABr, SigmaAldrich) by dissolving CTMABr at $313 \mathrm{~K}$ under stirring for $3 \mathrm{~h}$. The appropriate amounts (depending on the assumed Ce $: \mathrm{Zr}$ ratio) of zirconium $n$-tetrapropanol $\left(\mathrm{Zr}\left(\mathrm{OC}_{3} \mathrm{H}_{7}\right)_{4}, 70 \%\right.$ in $n$ propanol, Fluka) and powder of cerium(III) nitrate $\left(\mathrm{Ce}\left(\mathrm{NO}_{3}\right)_{3^{-}}\right.$ $\cdot 6 \mathrm{H}_{2} \mathrm{O}$, Sigma-Aldrich) were added into the above-mentioned solution with a surfactant/precursors molar ratio of 0.33 . After further stirring for $1 \mathrm{~h}$ at $313 \mathrm{~K}$, the mixture was heated at $353 \mathrm{~K}$ for $24 \mathrm{~h}$. The template was removed by extraction in a Soxhlet apparatus at $351 \mathrm{~K}$ using ethanol for $30 \mathrm{~h}$. Then, the oxide was dried in a vacuum rotator at $343 \mathrm{~K}(200-300 \mathrm{mbar})$ and calcined at $673 \mathrm{~K}$ for $4 \mathrm{~h}$ at the heating rate of $3 \mathrm{~K} \mathrm{~min}^{-1}$. The final materials were obtained after calcination at $673 \mathrm{~K}$ for $4 \mathrm{~h}$ at the heating rate of $3 \mathrm{~K} \mathrm{~min}^{-1}$. The organic template and other carbonates were removed by the calcination.

2.1.3. Preparation of mixed cerium-zirconium oxide $\mathbf{C e Z r O}_{x}(\mathbf{C e}: \mathbf{Z r}=\mathbf{2}: \mathbf{1})$. The syntheses of mixed cerium-zirconium oxide, $\mathrm{CeZrO}_{x}(\mathrm{Ce}: \mathrm{Zr}=2: 1)$ was carried out using a solution of organic copolymer - Pluronic P-123 (polyethyl glycol-polypropyl glycol-polyethyl glycol, Sigma-Aldrich) in ethanol (POCh). A portion of $1.2 \mathrm{~g}$ of Pluronic P-123 was dissolved in $12 \mathrm{~cm}^{3}$ of ethanol. P123 was mixed with ethanol at room temperature for $1 \mathrm{~h}$, then powders of metals sources -
cerium(III) nitrate $\left(\mathrm{Ce}\left(\mathrm{NO}_{3}\right)_{3} \cdot 6 \mathrm{H}_{2} \mathrm{O}\right.$, Sigma-Aldrich) and zirconium oxonitrate(v) $\left(\mathrm{ZrO}\left(\mathrm{NO}_{3}\right)_{2}\right.$, Sigma-Aldrich), were added to ethanol solution of the template and the mixture was stirred for $1 \mathrm{~h}$. In the sample of $\mathrm{CeZrO}_{x}(2: 1)$, the ratio of ceria : zirconia was $2: 1$. The final material was obtained by heating the mixture at $673 \mathrm{~K}$ for $10 \mathrm{~h}$ in air atmosphere (a heating rate of $1 \mathrm{~K}$ $\left.\min ^{-1}\right)$. The supports prepared were labelled as $\mathrm{XYO}_{x}(\mathrm{~A}: \mathrm{B})$ where $\mathrm{X}=\mathrm{Ce} ; \mathrm{Y}=\mathrm{Zr}$; $\mathrm{A}: \mathrm{B}=$ ceria : zirconia nominal molar ratio. Calcination removed the organic template and other carbonates.

The main reason of change in the procedure of oxides preparation was the achievement of a high yield of the synthesis. The usage of CTMABr was effective only in the case of small amount of cerium in the synthesis mixture (i.e. the nominal molar ratio $\mathrm{CeO}_{2}: \mathrm{ZrO}_{2}=1: 1$ and $1: 2$ ). For a higher cerium content the change of the template was necessary. Therefore, for the sample with the nominal molar ratio of $\mathrm{CeO}_{2}: \mathrm{ZrO}_{2}=2: 1$ and $\mathrm{CeO}_{2}$ we used Pluronic P-123 as a template.

2.1.4. Preparation of ceria. The synthesis of pure ceria, $\mathrm{CeO}_{2}$ was carried out using a solution of organic copolymer Pluronic P-123 (polyethyl glycol-polypropyl glycol-polyethyl glycol, Sigma-Aldrich) in ethanol (POCh). A portion of $1.2 \mathrm{~g}$ of Pluronic P-123 was dissolved in $12 \mathrm{~cm}^{3}$ of ethanol. P123 was mixed with ethanol at room temperature for $1 \mathrm{~h}$, then powders of metal source - cerium(III) nitrate $\left(\mathrm{Ce}\left(\mathrm{NO}_{3}\right)_{3} \cdot 6 \mathrm{H}_{2} \mathrm{O}, \geq 99.99 \%\right.$, Sigma-Aldrich) was added to ethanol solution of the template and was stirred for $1 \mathrm{~h}$ at room temperature. The final material was obtained by heating the mixture at $673 \mathrm{~K}$ for $10 \mathrm{~h}$ in air (a heating rate of $1 \mathrm{~K} \mathrm{~min}^{-1}$ ).

2.1.5. Modification of mesoporous oxides with gold. The modification of mesoporous oxides with $1.5 \mathrm{wt} \%$ of $\mathrm{Au}$ species was realised as follows. A portion of $4.500 \mathrm{~g}$ of dried material (ceria, zirconia or ceria-zirconia oxides) was modified according to the literature method. ${ }^{\mathbf{4 0 - 4 2}}$ Urea was used as precipitation agent to form solid nanoparticles of gold hydroxide obtained by hydrolysis of gold precursor (tetrachloroauric acid ( $\mathrm{HAuCl}_{4}$ $\cdot 3 \mathrm{H}_{2} \mathrm{O}$ ), Johnson-Matthey). The method of gold deposition using urea and washing with ammonia aqua solution was used according to the procedure described in ref. 40 to obtain small gold particles (below $5 \mathrm{~nm}$ ). A portion of $137 \mathrm{mg}$ of tetrachloroauric acid was added to $217 \mathrm{~cm}^{3}$ of distillate water. Then aqua solution of urea (99\%, Fluka, $0.16 \mathrm{~mol} \mathrm{dm}^{-3}$ ) was added (molar ratio of urea/gold was 100). Finally the support (ceria, zirconia or ceria-zirconia oxides) was included into such obtained solution $(\mathrm{pH}=2)$. The mixture was stirred in a quartz flask for $4 \mathrm{~h}$ at $353 \mathrm{~K}$. Then the product was filtered and washed with $100 \mathrm{~cm}^{3}$ of aqua solution of ammonia $\left(25 \%, \mathrm{NH}_{3} \cdot \mathrm{H}_{2} \mathrm{O}\right.$, Chempur) and $850 \mathrm{~cm}^{3}$ of distilled water to obtain $\mathrm{pH}=7$. The product was dried at room temperature for $24 \mathrm{~h}$ and final material was obtained after calcination at $623 \mathrm{~K}$ for $3 \mathrm{~h}$. Thus, five gold catalysts: $\mathrm{Au} / \mathrm{CeO}_{2}, \mathrm{Au} / \mathrm{CeZrO}_{x}(2: 1), \mathrm{Au} / \mathrm{CeZrO}_{x}(1: 1)$, $\mathrm{Au} / \mathrm{CeZrO}_{x}(1: 2)$ and $\mathrm{Au} / \mathrm{ZrO}_{2}$ were obtained.

2.1.6. Introduction of copper by incipient wetness impregnation. Copper was introduced by incipient wetness impregnation to get $2.0 \mathrm{wt} \%$ of copper. Before impregnation, the support was dried using a vacuum rotator (200-300 mbar) at 
343-348 K for $1 \mathrm{~h}$. The source of copper, i.e. $0.146 \mathrm{~g}$ of copper(II) nitrate $\mathrm{Cu}\left(\mathrm{NO}_{3}\right)_{2} \cdot 2.5 \mathrm{H}_{2} \mathrm{O}$ (Sigma-Aldrich) was dissolved at room temperature in $2 \mathrm{~cm}^{3}$ of distilled water and used to fill the oxide pores. The wetted oxide was dried under vacuum at $343 \mathrm{~K}$ for $1 \mathrm{~h}$, then at $333 \mathrm{~K}$ for $16 \mathrm{~h}$ at atmospheric pressure. The materials were calcined in an oven at $623 \mathrm{~K}$ for $3 \mathrm{~h}$ (a heating rate of 3 $\mathrm{K} \min ^{-1}$ ). The following catalysts were obtained: $\mathrm{Cu} / \mathrm{CeO}_{2}, \mathrm{Cu} /$ $\mathrm{CeZrO}_{x}(2: 1), \mathrm{Cu} / \mathrm{CeZrO}_{x}(1: 1), \mathrm{Cu} / \mathrm{CeZrO}_{x}(1: 2)$ and $\mathrm{Cu} / \mathrm{ZrO}_{2}$.

2.1.7. Modification of gold-containing samples with copper species. To introduce copper into samples by incipient wetness impregnation, portions of $2.000 \mathrm{~g}$ of dried $\mathrm{Au}-$ containing catalysts were treated with $2 \mathrm{~cm}^{3}$ of aqueous solution of $\mathrm{Cu}\left(\mathrm{NO}_{3}\right)_{2} \cdot 2.5 \mathrm{H}_{2} \mathrm{O}(0.146 \mathrm{~g}$, Sigma-Aldrich). Before impregnation, the support was dried using a vacuum rotator (200-300 mbar) at 343-348 $\mathrm{K}$ for $1 \mathrm{~h}$. The amount of copper nitrate used for the modification was calculated to achieve the loading of copper equal to $2 \mathrm{wt} \%$. The $\mathrm{CuAu} / \mathrm{CeO}_{2}, \mathrm{CuAu} /$ $\mathrm{CeZrO}_{x}(2: 1), \mathrm{CuAu} / \mathrm{CeZrO}_{x}(1: 1), \mathrm{CuAu} / \mathrm{CeZrO}_{x}(1: 2), \mathrm{CuAu} /$ $\mathrm{ZrO}_{2}$ materials were dried under vacuum at $343 \mathrm{~K}$ for $1 \mathrm{~h}$, then at $333 \mathrm{~K}$ for $16 \mathrm{~h}$ at atmospheric pressure and then calcined at 623 $\mathrm{K}$ for $3 \mathrm{~h}$.

\subsection{Catalyst characterization}

2.2.1. $\mathrm{N}_{2}$ adsorption and desorption isotherms. The $\mathrm{N}_{2}$ adsorption/desorption isotherms were obtained using a Quantachrome Instruments autosorb iQ2 at $77 \mathrm{~K}$. The samples were pre-treated in situ under vacuum at $573 \mathrm{~K}$ for $4 \mathrm{~h}$.

The nitrogen adsorption isotherms for $\operatorname{CeZrO}_{x}(1: 1), \mathrm{Au} /$ $\mathrm{CeZrO}_{x}(1: 1), \mathrm{Cu} / \mathrm{CeZrO}_{x}(1: 1)$ and $\mathrm{CuAu} / \mathrm{CeZrO}_{x}(1: 1)$ were obtained using a ASAP 2020 Instruments at $77 \mathrm{~K}$ after pretreated in situ under high vacuum at $573 \mathrm{~K}$ for $8 \mathrm{~h}$. The surface area was calculated by the BET method. Mesopores volume and mean pore size were determined from $\mathrm{BJH}$ (adsorption branches).

2.2.2. X-ray diffraction (XRD). XRD measurements were carried out on a Bruker AXS D8 Advance diffractometer with $\mathrm{Cu}$ $\mathrm{K}_{\alpha}$ radiation $(\lambda=0.154 \mathrm{~nm})$, with a step size of $0.5^{\circ}$ in the wideangle range $\left(21-81^{\circ}\right)$. The XRD method was used to estimate the size of gold particles using the Scherrer formula.

2.2.3. Ultra-violet spectroscopy (UV-vis spectroscopy). UVvis spectra were recorded using a Varian-Cary 300 Scan UVvisible spectrophotometer. Powder calcined samples after drying at $383 \mathrm{~K}$ for $13 \mathrm{~h}$ were placed in a cell equipped with a quartz window. The spectra were recorded in the range from 800 to $190 \mathrm{~nm}$. Spectralon ${ }^{\circledR}$ was used as the reference material.

2.2.4. STEM-EDXS (scanning-transmission electron microscopy-edge differential X-ray spectroscopy). Metal particles of gold were characterized using scanning transmission electron microscopy (STEM) and estimated using Image $\mathrm{J}^{\mathrm{TM}}$ software. STEM images were acquired with an aberrationcorrected dedicated STEM microscope HD 2700 CS (Hitachi, acceleration potential of $200 \mathrm{kV}$ ) and obtained with a high-angle annular dark-field (HAADF) detector to produce images with atomic number $(Z)$ contrast. The size distribution and average size of gold particles were estimated from STEM images using ImageJ software. The precision of particle size determination was $c a . \pm 0.5 \mathrm{~nm}$. Finally, the fractions of gold particles of the same size in all gold particles were calculated to determine the particle size distribution.

2.2.5. $\mathrm{H}_{2}$-TPR (temperature programmed reduction by hydrogen). Temperature-programmed reduction $\left(\mathrm{H}_{2}\right.$-TPR) was performed using a CATLAB system connected to a mass spectrometer using a flow of hydrogen as a reducing agent. At the beginning, a calcined catalyst $(0.040 \mathrm{~g})$ in the form of powder was packed into the tube quartz reactor and connected to the CATLAB device. Then, the sample was heated in a flow of helium and argon (He/Ar - 90/10 vol\%, total flow rate of $40 \mathrm{~cm}^{3}$ $\mathrm{min}^{-1}$ ) for $40 \mathrm{~min}$ at $313 \mathrm{~K}$ for the stabilization of signals from the mass spectrometer. After this time, the mixture of gases was changed into the final reducing mixture: $\mathrm{H}_{2} / \mathrm{Ar} / \mathrm{He}\left(5 \mathrm{vol} \% \mathrm{H}_{2}\right.$, $10 \mathrm{vol} \% \mathrm{Ar}$ and $85 \mathrm{vol} \% \mathrm{He}$, total flow rate of $40 \mathrm{~cm}^{3} \mathrm{~min}^{-1}$ ). After $20 \mathrm{~min}$, the signals of mass ions were stable and the heating started from $313 \mathrm{~K}$ to $1173 \mathrm{~K}$ at the heating rate of $10 \mathrm{~K}$ $\min ^{-1}$. A quadruple mass spectrometer measured the signals of mass ions for $m / z=2.00\left(\mathrm{H}_{2}\right), 18.00\left(\mathrm{H}_{2} \mathrm{O}\right), 32.00\left(\mathrm{O}_{2}\right)$ and 36.00 (Ar). The TPR profiles presented the correlation between hydrogen consumption and increasing temperature. The TPR profile recorded for the reactor without the catalyst was subtracted from those recorded with the catalysts.

2.2.6. XPS (X-ray photoelectron spectroscopy) study. X-ray photoelectron spectra were recorded on an Ultra High Vacuum (UHV) System. The study was conducted using X-ray Al $\mathrm{K}_{\alpha}=1486.6 \mathrm{eV}$ with the following lamp parameters: $14.5 \mathrm{kV}, 20$ $\mathrm{mA}$. Measurements were carried out in the chamber of the analyser under vacuum of approximately $2.0 \times 10^{-8} \mathrm{mbar}$. The spectra were recorded for the energy range from $1100 \mathrm{eV}$ to $0 \mathrm{eV}$ in increments of $0.5 \mathrm{eV}$, the energy transition CAE $=100 \mathrm{eV}$. Different regions were recorded in increments of $0.1 \mathrm{eV}$, the energy transition $\mathrm{CAE}=30 \mathrm{eV}$ and time counts $50 \mathrm{~ms}$. The number of scans in the measured range was fitted to the observed signal to noise ratio. The powder sample was put on the conductive tape of carbon (graphite), which was adhered to the carrier surface and placed perpendicular to the axis of the analyser. The X-ray source was set at the angle of $60^{\circ}$ to the plane of the surface. The area of the samples analysed corresponded to the size of the aperture of the analyser used (large area), ca. $50 \mathrm{~mm}^{2}$. Deconvolution of XP spectra was carried out using the OMNIC 8.0 ${ }^{\mathrm{TM}}$ software. Bands intensities were estimated by calculating the integral of each band after smoothing and baseline correction. Then the deconvolution parameters for the experimental curve, that is the Voigt function, small signal sensitivity and constant base line, were chosen in the OMNIC 8.0 ${ }^{\mathrm{TM}}$ software. Atomic ratios were computed from the intensity ratios normalized by the atomic sensitivity factors. An estimated error of $\pm 0.1 \mathrm{eV}$ can be assumed for all measurements.

\subsection{Catalytic activity - glycerol oxidation in the liquid phase}

2.3.1. Reaction conditions. Glycerol oxidation experiments were performed in a $25 \mathrm{~cm}^{3}$ batch reactor Berghof-25 (Germany) equipped with temperature and pressure controllers. The oxidation reactions were carried out in the presence of oxygen (Linde, $5.0 \mathrm{~N}$ ) under pressure of $6 \mathrm{~atm}$ and $0.0030 \mathrm{~mol}(0.120 \mathrm{~g})$ 
of sodium hydroxide, $\mathrm{NaOH}$ (Merck, >99.0\%, $\mathrm{NaOH}$ : glycerol molar ratio $=2: 1) .15 .00 \mathrm{~g}$ of distillate water was put into the reactor, then $0.0015 \mathrm{~mol}(0.138 \mathrm{~g})$ of glycerol (Sigma-Aldrich, $>99.0 \%)$, a base $-\mathrm{NaOH}(0.12 \mathrm{~g})$ and $0.030 \mathrm{~g}$ of catalyst were added and the autoclave was closed. Oxygen was introduced to the autoclave at the selected pressure and the mixture was heated to 333 or $363 \mathrm{~K}$ (a heating rate $2 \mathrm{~K} \mathrm{~min}^{-1}$ ) and stirring at $400,800,1000$ or $1200 \mathrm{rpm}$. The time of reaction was initiated by stirring at the moment when the mixture achieved the selected temperature. The reaction was conducted for $5 \mathrm{~h}$ at a selected temperature and stirring speed before analysis of products. The oxygen content was estimated by the electronic sensor of pressure which measured the pressure of oxygen in the real time of the reaction.

2.3.2. Analyses of products. The quantitative analyses of the reaction mixtures were performed using a high performance liquid chromatograph Merck Hitachi HPLC L-7000 series and the products of the reaction were analysed by a VWR Hitachi Chromaster RI Detector. The reactant and the products were separated on an ion exchange Aminex HPX-87H HPLC column heated at $308 \mathrm{~K}$. The eluent was an aqua solution of $\mathrm{H}_{2} \mathrm{SO}_{4}$ $(0.005 \mathrm{M})$ and its flow rate was set at $0.6 \mathrm{~cm}^{3} \mathrm{~min}^{-1}$. The samples were taken at the end of the reaction: $1 \mathrm{~cm}^{3}$ of the reactant/products solution was diluted in $10 \mathrm{~cm}^{3}$ of water and $10 \mu \mathrm{l}$ of such solution was analysed. The conversion of glycerol and selectivity to selected products were calculated by comparing the area of chromatographic peaks recorded for sample solutions with those of substrate respectively products found in calibration curves. Calibration curves aqua solutions (in the range $0.01-0.10 \mathrm{M}$ ) using pure chemical reagents: glycerol (Sigma-Aldrich, 99\%), lactic acid (Sigma-Aldrich, 90\%), tartronic acid (Fluka, 97\%), glycolic acid (Sigma-Aldrich, 99\%), oxalic acid (Sigma-Aldrich, 99\%), glyceraldehyde (Sigma, 90\%), formic acid (Sigma-Aldrich, 98\%), glyoxylic acid (Sigma-Aldrich, 95\%), 1,3-dihydroxyacetone (Sigma-Aldrich, aqua solution $50 \%$ ), glyceric acid (Sigma-Aldrich, aqua solution 20\%) and $\mathrm{NaOH}$ (Merck, $>99.0 \%$ ). Four aqua solutions were prepared for each reagent. The concentrations of these solutions were 0.01 , $0.02,0.05$ and $0.10 \mathrm{M}$ and $\mathrm{pH}$ was 13.3 . Then $1 \mathrm{~cm}^{3}$ of each solution was diluted in $10 \mathrm{~cm}^{3}$ of water and $10 \mu \mathrm{l}$ of such solution was analysed using high performance liquid chromatography. The areas of chromatographic peaks were related to the concentrations of reagents by a straight line, using linear regression analysis. The glycerol conversion and the selectivities to the products of glycerol oxidation were described by the equation: $y=a x+b$, where $y$ was the instrument response, $a$ represented the sensitivity, and $b$ was a constant that described the background. The concentration $(x)$ of reagent in the solution after reaction was calculated from this equation.

\section{Results and discussion}

\subsection{Structure of the supports}

Undoped zirconia has the monoclinic structure, ${ }^{24}$ which is a distorted fluorite-type or tetragonal structure. Pure ceria is cubic. The structure of mixed ceria-zirconia oxides strongly depends on the composition and the preparation conditions.
With increasing cerium content, the monoclinic structure of mixed oxide solid solution changes to a mixture of monoclinic, tetragonal, pure tetragonal and cubic structures. ${ }^{24}$ The type of structure and chemical composition are reflected by the stability of the system and the isotropic atomic displacement parameter of oxygen atoms, $U(\mathrm{O})$. This parameter is a good indicator of oxygen diffusivity, which is important in catalytic oxidation reactions. High $U(\mathrm{O})$ values indicate a high static positional disorder and a high dynamic thermal vibration, which enhance the movement of oxide ions across the material. Yashima and Wakita ${ }^{43}$ found that $\mathrm{Ce}_{0.5} \mathrm{Zr}_{0.5} \mathrm{O}_{2}$ shows the highest value of $U(\mathrm{O})$ among the materials with different ceria to zirconia ratios. We used three different ceria to zirconia ratios: $2: 1,1: 1$ and $1: 2$. The XRD pattern (Fig. 1) of ceria was characteristic of its cubic phase (JCPDS ICDD PDF card - 00-0431002). The pattern of zirconia identified its structure as a mixture of tetragonal (JCPDS ICDD PDF card - 00-042-1164) and monoclinic (JCPDS ICDD PDF card - 00-007-0343) phases. The XRD patterns of the mixed oxides varied with the chemical composition (Fig. 1). In the samples with a ceria to zirconia ratio of $2: 1$, the ceria and zirconia phases showed independent XRD patterns. The intensity of the zirconia phase was very low, which is in agreement with the low content of zirconia. Increasing the amount of zirconia to a ceria : zirconia ratio of $1: 2$ induced asymmetry in the peaks in the XRD patterns; peaks characteristic of both zirconia and ceria, with a slight domination of those from zirconia, were present. Contrary to pure zirconia, which contains both monoclinic and tetragonal structures, the mixture of ceria-zirconia with molar ratio of $1: 2$ exhibits the presence of only tetragonal zirconia. At equimolar ceria and zirconia ratio, weak reflections of ceria were visible. The structure of zirconia with a uniform distribution of cerium ions within this phase can be assumed.

The differences in the phase compositions also affect the textural parameters determined from nitrogen adsorption/ desorption isotherms (Fig. S1, $\uparrow$ Table 1). The isotherms were of type IV indicating mesoporous materials. Ceria, zirconia, and $\mathrm{CeZrO}_{x}(1: 2)$ contained small amounts of micropores. Because of larger microporosity, the surface area of zirconia is much higher $\left(121 \mathrm{~m}^{2} \mathrm{~g}^{-1}\right)$ than that of ceria $\left(25 \mathrm{~m}^{2} \mathrm{~g}^{-1}\right)$. The inclusion of a small amount of zirconia into ceria (ceria : zirconia $=2: 1$ ) decreased the surface area to $16 \mathrm{~m}^{2} \mathrm{~g}^{-1}$. Further increasing the zirconium content led to a slight increase of the surface area to 103 and $108 \mathrm{~m}^{2} \mathrm{~g}^{-1}$ for $\operatorname{CeZrO}_{x}(1: 1)$ and $\operatorname{CeZrO}_{x}(1: 2)$, respectively.

\subsection{Chemical composition}

Table 2 shows the composition of the catalysts. The values estimated from ICP-MS analyses were similar to those assumed in the preparation, i.e., the molar ceria : zirconia ratio of $c a$. $2: 1,1: 1$ and $1: 2$. The modification of all mixed oxide supports, especially by gold, decreased the molar ratio of ceria : zirconia. Thus, metal addition led to a partial removal of cerium by the interaction of ceria with tetrachloroauric. Notably, a higher percentage of cerium removal was observed for $\mathrm{CeZrO}_{x}(1: 1)$; about $25 \%$ compared to $0-14 \%$ for the others. 

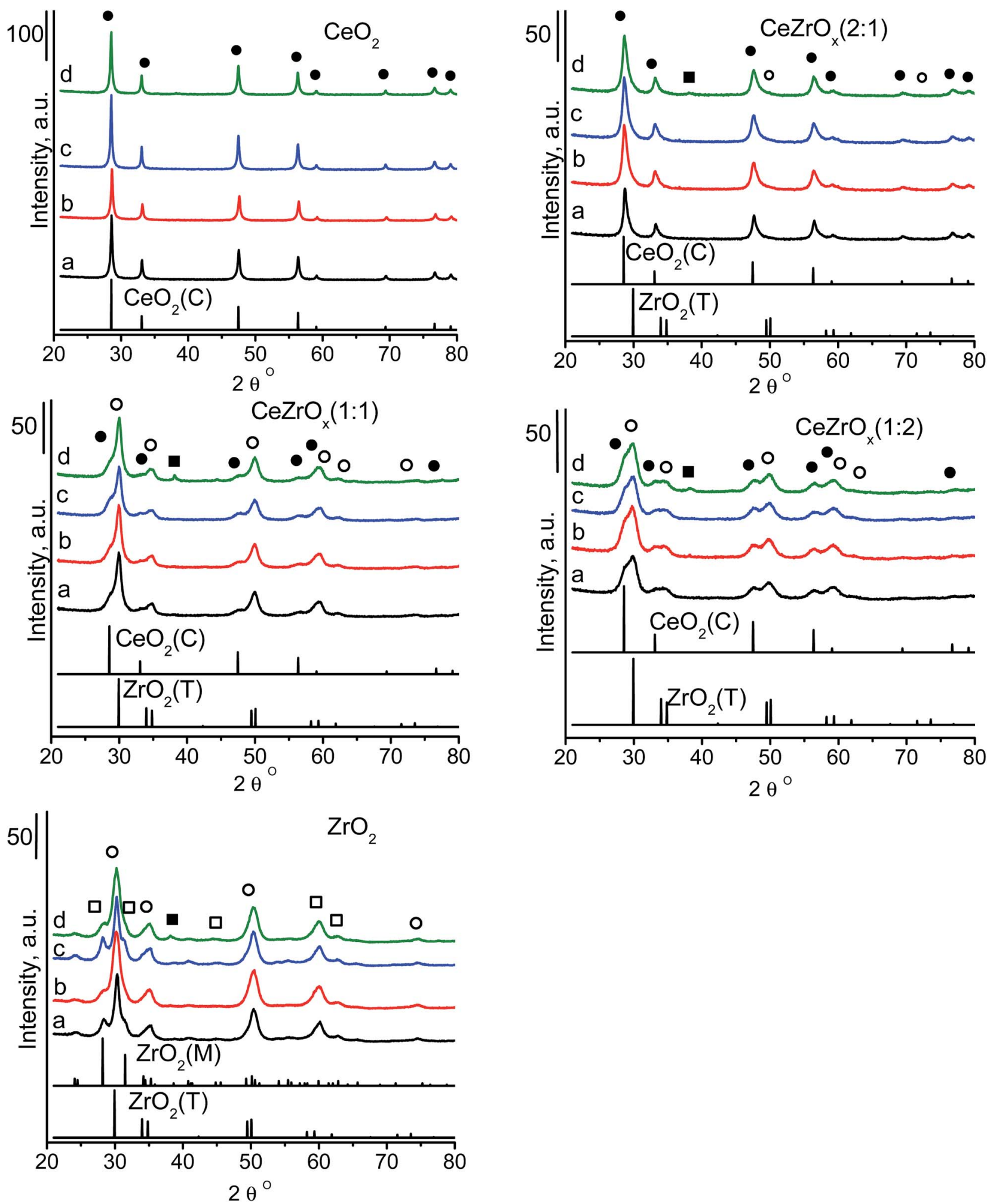

Fig. 1 XRD patterns of catalysts: (a) supports, (b) Au catalysts, (c) Cu catalysts, (d) Cu-Au catalysts, where - cubic crystal structure of ceria $\mathrm{CeO}_{2}(\mathrm{C}), \mathrm{O}$ - tetragonal crystal structure of zirconia $\mathrm{ZrO}_{2}(\mathrm{~T}), \square-$ monoclinic crystal structure of zirconia $\mathrm{ZrO}_{2}(\mathrm{M}), \mathbf{\square}-\mathrm{metallic}$ gold Au ${ }^{0}$.

The efficiency of copper introduction was higher than that of gold. On all the supports, the copper loading was in the range of 1.4-1.8 wt\%, introducing $2.0 \mathrm{wt} \%$ during the synthesis. Gold introduction ranged between 0.6 and $1.1 \mathrm{wt} \%$, intending 1.5 $w t \%$. More gold was incorporated on pure ceria than on pure zirconia and for copper, this was the similar. If copper was loaded on the supports already modified with gold species, the total amount of copper introduced onto ceria was greater, 
Table 1 Structure/texture parameters of catalysts

\begin{tabular}{|c|c|c|c|c|c|}
\hline Catalyst & $\begin{array}{l}\text { Surface area, } \\
\mathrm{m}^{2} \mathrm{~g}^{-1}(\mathrm{BET})\end{array}$ & $\begin{array}{l}\text { Av. pore diameters, } \mathrm{nm} \\
(\text { ads. } \mathrm{BJH})\end{array}$ & $\begin{array}{l}\text { Total pore volume, } \\
\mathrm{cm}^{3} \mathrm{~g}^{-1}\end{array}$ & $\begin{array}{l}\text { Micropore volume, } \\
\mathrm{cm}^{3} \mathrm{~g}^{-1}\end{array}$ & $\begin{array}{l}\text { Mesopore volume, } \\
\mathrm{cm}^{3} \mathrm{~g}^{-1}\end{array}$ \\
\hline $\mathrm{CeO}_{2}$ & 24 & 4.7 & 0.06 & 0.004 & 0.05 \\
\hline $\mathrm{Cu} / \mathrm{CeO}_{2}$ & 22 & 3.1 & 0.06 & 0.002 & 0.06 \\
\hline $\mathrm{CuAu} / \mathrm{CeO}_{2}$ & 24 & 3.1 & 0.06 & 0.005 & 0.05 \\
\hline $\mathrm{CeZrO}_{x}(2: 1)$ & 16 & 4.0 & 0.07 & 0.002 & 0.07 \\
\hline $\mathrm{CuAu} / \mathrm{CeZrO}_{x}(2: 1)$ & 20 & 3.0 & 0.06 & - & 0.06 \\
\hline $\mathrm{CeZrO}_{x}(1: 1)$ & 103 & 7.2 & 0.14 & - & 0.13 \\
\hline $\mathrm{Au} / \mathrm{CeZrO}_{x}(1: 1)$ & 65 & 9.7 & 0.10 & 0.003 & 0.10 \\
\hline $\mathrm{Cu} / \mathrm{CeZrO}_{x}(1: 1)$ & 67 & 7.1 & 0.13 & 0.005 & 0.12 \\
\hline $\mathrm{CuAu} / \mathrm{CeZrO}_{x}(1: 1)$ & 62 & 9.7 & 0.10 & 0.003 & 0.10 \\
\hline $\mathrm{CeZrO}_{x}(1: 2)$ & 108 & 3.0 & 0.19 & 0.036 & 0.15 \\
\hline $\mathrm{Au} / \mathrm{ZrO}_{2}$ & 114 & 3.1 & 0.26 & 0.041 & 0.22 \\
\hline $\mathrm{Cu} / \mathrm{ZrO}_{2}$ & 123 & 3.0 & 0.21 & 0.046 & 0.16 \\
\hline $\mathrm{CuAu} / \mathrm{ZrO}_{2}$ & 110 & 3.0 & 0.34 & 0.034 & 0.30 \\
\hline
\end{tabular}

Table 2 Chemical composition of the catalysts (basing on ICP-OES and XPS results)

\begin{tabular}{|c|c|c|c|c|c|}
\hline \multirow[b]{2}{*}{ Catalyst } & \multicolumn{2}{|c|}{ Content of metal species, wt $\%$} & \multirow{2}{*}{$\begin{array}{l}\text { Gold : copper } \\
\text { molar ratio } \\
\text { ICP/XPS }\end{array}$} & \multicolumn{2}{|c|}{ Ceria : zirconia molar ratio } \\
\hline & $\mathrm{Au}, \mathrm{ICP} / \mathrm{XPS}$ & $\mathrm{Cu}, \mathrm{ICP} / \mathrm{XPS}$ & & ICP/XPS & As assumed \\
\hline $\mathrm{CeO}_{2}$ & - & - & $-1-$ & $-1-$ & - \\
\hline $\mathrm{CeZrO}_{x}(2: 1)$ & - & - & $-1-$ & $2.8 / 4.7$ & 2.0 \\
\hline $\mathrm{CeZrO}_{x}(1: 1)$ & - & - & $-1-$ & $0.8 / 0.9$ & 1.0 \\
\hline $\mathrm{CeZrO}_{x}(1: 2)$ & - & - & $-1-$ & $0.5 / 0.5$ & 0.5 \\
\hline $\mathrm{ZrO}_{2}$ & - & - & $-1-$ & $-1-$ & - \\
\hline $\mathrm{Au} / \mathrm{CeO}_{2}$ & $1.0 / 10.0$ & - & $-1-$ & $-1-$ & - \\
\hline $\mathrm{Au} / \mathrm{CeZrO}_{x}(2: 1)$ & $1.1 / 1.7$ & - & $-1-$ & $2.4 / 2.4$ & 2.0 \\
\hline $\mathrm{Au} / \mathrm{CeZrO}_{x}(1: 1)$ & $1.0 / 9.1$ & - & $-1-$ & $0.6 / 0.5$ & 1.0 \\
\hline $\mathrm{Au} / \mathrm{CeZrO}_{x}(1: 2)$ & $1.0 / 6.7$ & - & $-1-$ & $0.4 / 0.6$ & 0.5 \\
\hline $\mathrm{Au} / \mathrm{ZrO}_{2}$ & $0.6 / 2.6$ & - & $-1-$ & $-1-$ & - \\
\hline $\mathrm{Cu} / \mathrm{CeO}_{2}$ & - & $1.4 / 5.0$ & $-1-$ & $-1-$ & - \\
\hline $\mathrm{Cu} / \mathrm{CeZrO}_{x}(2: 1)$ & - & $1.7 / 3.1$ & $-1-$ & $2.8 / 2.3$ & 2.0 \\
\hline $\mathrm{Cu} / \operatorname{CeZrO}_{x}(1: 1)$ & - & $1.6 / 1.1$ & $-1-$ & $0.5 / 0.5$ & 1.0 \\
\hline $\mathrm{Cu} / \mathrm{CeZrO}_{x}(1: 2)$ & - & $1.5 / 2.0$ & $-1-$ & $0.4 / 1.2$ & 0.5 \\
\hline $\mathrm{Cu} / \mathrm{ZrO}_{2}$ & - & $1.8 / 1.0$ & $-1-$ & $-1-$ & - \\
\hline $\mathrm{CuAu} / \mathrm{CeO}_{2}$ & $1.0 / 8.2$ & $1.7 / 2.7$ & $0.18 / 0.99$ & $-1-$ & - \\
\hline $\mathrm{CuAu} / \mathrm{CeZrO}_{x}(2: 1)$ & $1.0 / 1.2$ & $1.6 / 1.3$ & $0.21 / 0.30$ & $2.4 / 3.1$ & 2.0 \\
\hline $\mathrm{CuAu} / \mathrm{CeZrO}_{x}(1: 1)$ & $1.0 / 11.4$ & $1.7 / 2.1$ & $0.20 / 1.78$ & $0.5 / 1.0$ & 1.0 \\
\hline $\mathrm{CuAu} / \mathrm{CeZrO}_{x}(1: 2)$ & $1.0 / 3.9$ & $1.7 / 0.7$ & $0.19 / 1.70$ & $0.3 / 0.9$ & 0.5 \\
\hline $\mathrm{CuAu} / \mathrm{ZrO}_{2}$ & $0.6 / 0.9$ & $1.7 / 1.8$ & $0.12 / 0.16$ & $-1-$ & - \\
\hline
\end{tabular}

suggesting interaction between gold and copper during modification. The difference in gold concentration calculated from ICP and XPS, in which XPS is more surface sensitive, showed that gold was preferably located on the external surface of the oxides (Table 2). The surface concentration of the gold depended on the composition of the supports and was influenced by the admission of copper. The highest gold surface content was on $\mathrm{CeZrO}_{x}(1: 1)$ in the bimetallic (copper-gold) catalyst (11.4 $\mathrm{wt} \%$ ). The monometallic (gold) catalyst, based on the same support, exhibited a lower content of surface gold species (9.1 wt\%).

On all other supports, the concentration of surface gold was lower after copper loading. Loading copper involved the transfer of gold species into the bulk of these supports. In monometallic samples, the surface concentration of gold was higher on ceria than on zirconia. For cerium-zirconium mixed oxides, there was no obvious relationship between the ceria : zirconia ratio and the content of surface gold species. Similarly, copper 
content on the surface of the supports did not change linearly with the increase of zirconia. Notably, for monometallic copper on pure zirconia and $\operatorname{CeZrO}_{x}(1: 1)$, the concentration of copper on the surface was lower than the total content of copper, indicating partial incorporation of copper into the support. The same phenomenon was observed for some bimetallic samples.

This behavior indicates the mobility of the catalyst components and the dependence of the modifiers' location on the chemical composition of the support. Such mobility is enhanced by thermal treatments. ${ }^{23}$ The gold : copper molar ratio in most bimetallic catalysts is much higher on the surface of the material than in the bulk (Table 2). This difference is negligible only for $\mathrm{Cu}-\mathrm{Au}$ loaded on zirconia suggesting that in this material bimetallic species are distributed more uniformly. The surface and bulk concentrations of cerium and zirconium were estimated on the basis of the ceria : zirconia ratios (Table 2). The values of this ratio differed from the assumed ones. The higher ratio from the XPS analysis compared to ICP indicated enrichment of the surface in cerium. It was most clearly seen for $\mathrm{CeZrO}_{x}(2: 1)$ and all bimetallic catalysts.

\subsection{Texture/structure of catalysts}

Modification with copper species did not lead to the appearance of new reflections in the XRD patterns (Fig. 1). The XRD patterns of ceria-containing with only gold did not exhibit reflections from crystalline gold, suggesting the absence of large gold particles. Gold supported together with copper on ceriumzirconium oxides and pure zirconia $\left[\mathrm{CuAu} / \mathrm{ZrO}_{2}\right]$ gave a reflection at 2 theta at $c a .38^{\circ}$, which originates from metallic gold. ${ }^{5,44-46}$ Using the Scherrer equation, the average size of the particles in $\mathrm{CuAu} / \mathrm{CeZrO}_{x}(1: 1)$ and $\mathrm{CuAu} / \mathrm{ZrO}_{2}$ was $7.0 \mathrm{~nm}$ and $5.2 \mathrm{~nm}$, respectively.
Table 1 presents the textural/structural parameters of the materials modified with gold and/or copper and those of pristine supports. The surface areas of these samples ranged from $13\left[\mathrm{Au} / \mathrm{CeZrO}_{x}(2: 1)\right]$ to $123 \mathrm{~m}^{2} \mathrm{~g}^{-1}\left[\mathrm{Cu} / \mathrm{ZrO}_{2}\right]$. The samples based on zirconia were characterized by the highest surface area and with increasing cerium content, the surface area decreased. The addition of gold and/or copper slightly modified the surface area of the supports. The largest decrease in the surface area as a result of metal loading was observed on $\operatorname{CeZrO}_{x}(1: 1)$. The removal of cerium from this support during modification with metals may correlate to the decrease in the surface area. STEMEDXS analysis was used to estimate the relative composition and particle size distribution of supported particles. The bimetallic catalysts $\mathrm{CuAu} / \mathrm{CeZrO}_{x}(1: 1)$ and $\mathrm{CuAu} / \mathrm{ZrO}_{2}$ had average sizes of $2.2 \mathrm{~nm}$ (and a median particle size of $0.83 \mathrm{~nm}$ ) and $1.6 \mathrm{~nm}$ (with a median particle size of $0.73 \mathrm{~nm}$ ), respectively (Fig. 2). These values were smaller than those obtained from the XRD patterns using the Scherrer formula, which is dominated by the larger particles (7.0 and $5.2 \mathrm{~nm}$, respectively). The particle-size distribution was wider on zirconia than on the mixed oxides, but on both support types, it also covered the larger particles observed in XRD patterns. The differences in the size of gold particles measured by STEM-EDXS and XRD methods resulted from the differences in the resolution of both methods (XRD analysis does not indentify small metal particles). Notably, the average size of gold particles in the bimetallic sample $\mathrm{CuAu} / \mathrm{CeO}_{2}$ presented in the PSD diagram (Fig. 2) was greater than that noted on $\mathrm{CuAu} / \mathrm{ZrO}_{2}$ and $\mathrm{CuAu} / \mathrm{CeZrO}_{x}(1: 1)$. The comparison of the gold particle size distribution on pure zirconia support for monometallic $\left(\mathrm{Au} / \mathrm{ZrO}_{2}\right)$ and bimetallic $\left(\mathrm{CuAu} / \mathrm{ZrO}_{2}\right)$ systems indicated a decrease in the size of gold particles after the incorporation of copper. Thus, the
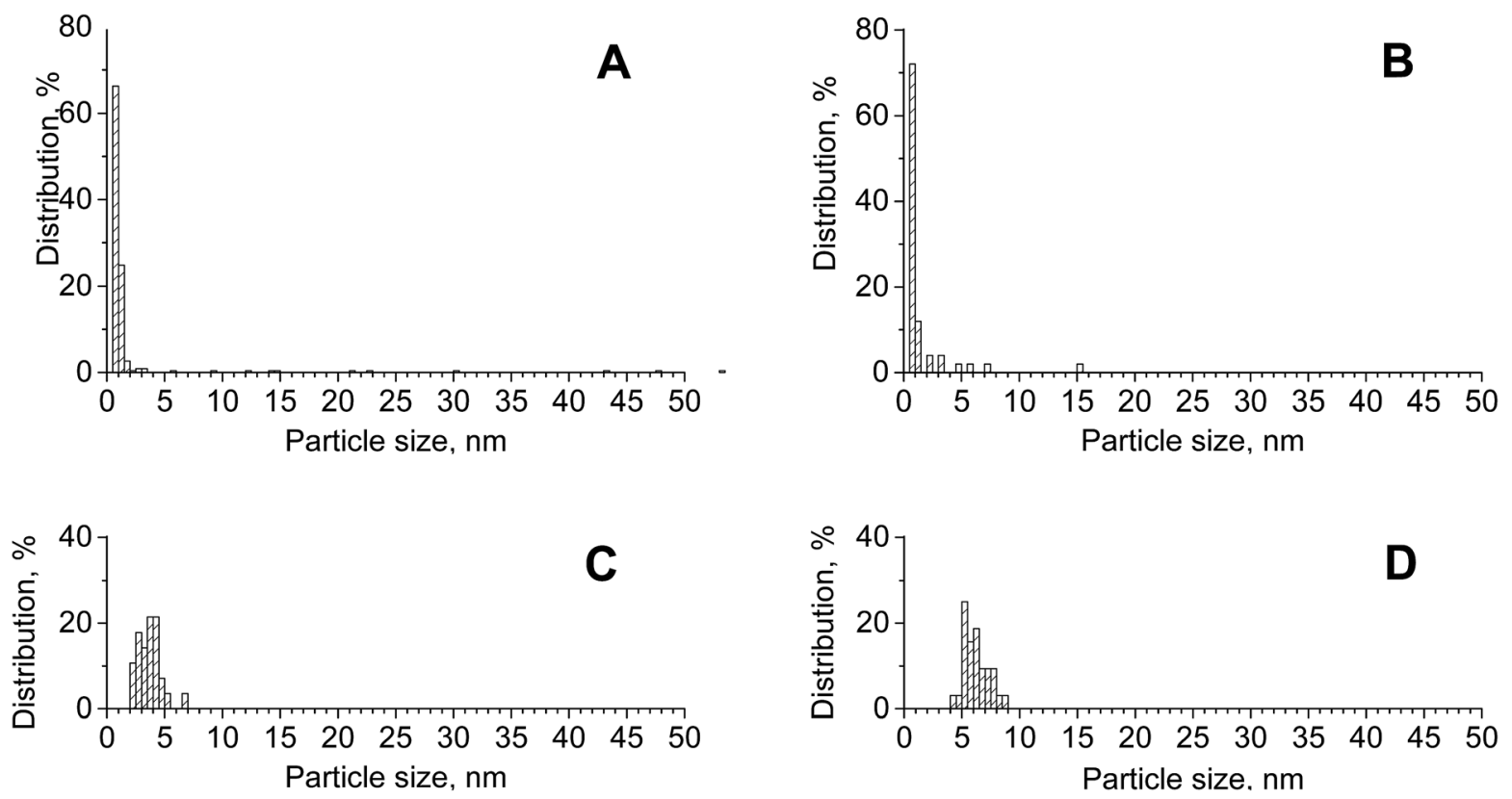

Fig. 2 Distribution of gold particle sizes on $[\mathrm{A}] \mathrm{CuAu} / \mathrm{CeZrO}_{x}(1: 1)\left(d_{\mathrm{av}}=2.2 \mathrm{~nm}\right.$, from 227 particles on STEM image), [B] CuAu/ZrO $2\left(d_{\mathrm{av}}=1.6 \mathrm{~nm}\right.$, from 50 particles on STEM image), [C] $\mathrm{CuAu} / \mathrm{CeO}_{2}\left(d_{\mathrm{av}}=3.6 \mathrm{~nm}\right.$, from 28 particles on STEM image) and [D] Au/ZrO $\left(d_{\mathrm{av}}=6.2 \mathrm{~nm}\right.$, from 28 particles on STEM image). 
incorporation of copper enhanced the dispersion of the particles. An important factor that affects the performance of multifunctional catalysts is the location of their components, which was studied for $\mathrm{CuAu} / \mathrm{CeZrO}_{x}(1: 1)$ material by STEMEDXS analysis. Fig. S2† shows STEM images and EDX results.

The distribution of cerium and zirconium was almost the same, confirming the formation of the mixed oxides. Gold and copper species are located in the same areas, which indicates that they are in close vicinity to each other.

Individual species of gold and copper respectively ceria and zirconia were difficult to identify in the STEM images, because their contrast is too similar (Fig. S2†). To determine the composition of the white particles with diameters in the range of 10-70 nm, EDXS spot analyses were performed. The EDX spectrum of area 1, (Fig. $\mathrm{S} 2 \dagger$ ), indicated that the main component in the catalysts at this spot is gold. Moreover, a high intensity of gold signals, small intensities of zirconium and copper signals and the lowest intensity of cerium signals revealed that gold, zirconium, and copper were present in the same area. The EDX spectrum of area 2 in Fig. S2 $\uparrow$ showed that not all signals were as intense; in particular, the signals assigned to gold were less pronounced. This suggested that the larger white particles in STEM images were clusters of mixed oxides of cerium and zirconium and/or copper oxide clusters, with smaller contributions of gold.

\subsection{Oxidation state of components}

3.4.1. UV-vis spectroscopy. Fig. 3 presents the UV-vis spectra of the catalysts after drying at $383 \mathrm{~K}$ for $13 \mathrm{~h}$. The UVvis spectra of the supports in Fig. 3Aa-Ca showed a band at approximately $225 \mathrm{~nm}$ and other broad bands centered at $c a$. 270-285 $\mathrm{nm}$ and 340-350 $\mathrm{nm}$. The lower coordination number of cerium surrounded by oxygen ions requires the higher energy for a charge transfer from oxygen ions to cerium cations. Therefore the first band was assigned to the charge transfer in crystalline ceria in tetrahedral coordination $\mathrm{CO}^{2-}$ to $\mathrm{Ce}^{4+}$ ligand to metal charge transfer). The bands at ca. 270-285 $\mathrm{nm}$ and 340$350 \mathrm{~nm}$ were attributed to the charge transfer from oxygen to cerium cations in hexa- or octacoordinated species or to cerium cations at in lower oxidation states. ${ }^{47}$

With increasing zirconium content in the mixed oxides (Fig. 3Da), the band at ca. $350 \mathrm{~nm}$ became less resolved than the band at ca. $270 \mathrm{~nm}$. This finding suggested that in the mixed oxides, the content of cerium cations at an oxidation state lower than +4 and/or coordination number higher than four decreased. The band at approximately $213 \mathrm{~nm}$ (Fig. 3Ea) is typical of a charge transfer from the $\mathrm{O}^{2-}$ to $\mathrm{Zr}^{4+}$ ion with tetrahedral configuration in zirconia crystallites. ${ }^{4-50}$ In the spectra of the mixed oxides, the bands attributed to charge transfers in ceria overlapped with those from the charge transfer in zirconia. After copper and gold loading on ceria, $\mathrm{CeZrO}_{x}(2: 1)$ and $\mathrm{CeZrO}_{x}(1: 2)$, the UV-vis bands coming from the charge transfer from oxygen to cerium cations were still present in the spectra, but with lower intensities. This finding indicated that both gold and copper interacted with the cerium cations, which could lead to changes in their oxidation states.
The details on the oxidation states of all components are further considered below in the analyses of the XPS data.

The UV-vis spectra of gold-containing samples showed the characteristic ultraviolet-visible band at ca. 525-555 nm, typical of metallic gold. ${ }^{51}$ This plasmon resonance band corresponds to metallic gold nanoparticles of about 2-6 $\mathrm{nm}$ and are in accordance with the literature data. ${ }^{40}$ The well-resolved metallic gold band was observed for the samples loaded with both copper and gold (spectra d in Fig. 3). The band at ca. $260 \mathrm{~nm}$, which can arise from either the charge-transfer transitions of $\mathrm{Au}^{3+}$ or $\mathrm{Au}^{+}$ ions with ligands or from the absorption caused by the transition of electrons between molecular orbitals of the few-atomic clusters $\mathrm{Au}_{n}(n<10),{ }^{52}$ could not be distinguished from the band coming from the charge transfer from oxygen to cerium cations.

The modification of supports with copper species changed the UV-vis spectra (Fig. 3Ac-Ec), which was visible for zirconia because in its spectrum, the region above $230 \mathrm{~nm}$ did not contain UV-vis bands characteristic of pristine zirconia. A new band at ca. $265 \mathrm{~nm}$ appeared. According to literature data, ${ }^{53-55}$ bands at 220-260 $\mathrm{nm}$ were assigned to the charge-transfer transitions from oxygen in the crystal lattice $\mathrm{O}^{2-}$ to an isolated copper ion, $\mathrm{Cu}^{2+}\left(\mathrm{O}^{2-} \rightarrow \mathrm{Cu}^{2+}\right.$; ligand to metal charge transfer). The changes in the UV-vis spectra of the samples containing cerium resulted from copper loading were less pronounced, because the charge transfer in cerium gave bands in the same region.

Fig. 3E showed that after gold loading, the broadened absorption line covered the whole range between 240 and $640 \mathrm{~nm}$, whereas the copper loaded on zirconia gave rise to two well-distinguished bands at 256 and weak in the region 400$600 \mathrm{~nm}$. For copper species, the first band was assigned to the charge-transfer transitions from oxygen ions in the crystal lattice of the support to isolated copper ions $\left(\mathrm{O}^{2-}\right.$ to $\left.\mathrm{Cu}^{2+}\right){ }^{54,55}$ The second band came from the $\mathrm{d}-\mathrm{d}$ transition of $\mathrm{Cu}^{2+}$ ions located in an octahedral environment. ${ }^{56}$ This band was also observed (although less intense) in the spectra of $\mathrm{Cu}$ / $\mathrm{CeZrO}_{x}(1: 2)$ and $\mathrm{Cu} / \mathrm{CeZrO}_{x}(1: 1)$, whereas in the UV-vis spectra of $\mathrm{Cu} / \mathrm{CeZrO}_{x}(2: 1)$ and $\mathrm{Cu} / \mathrm{CeO}_{2}$, the tail of the spectral line could overlap with the band discussed. This band was also assigned in literature ${ }^{57}$ to oligonuclear copper oxygen species: $\mathrm{Cu}^{\delta+} \cdots \mathrm{O}^{\delta-} \cdots \mathrm{Cu}^{\delta+}$. In the spectra of bimetallic systems (gold-copper), this band coexisted with the band assigned to d$\mathrm{d}$ transitions in metallic gold clusters.

3.4.2. X-ray photoelectron spectroscopy. XPS was used to obtain the oxidation states of the gold, copper, cerium, and zirconium. Table 3 presents the binding energies (BE) of gold, copper, and zirconium (Table 4 ) and their relative distribution. Cerium was present in two oxidation states, +3 and +4 , copper in two oxidation states, +1 and +2 , and gold in the metallic form, cationic species $(+\delta ; \delta \geq 1)$, and moreover metallic gold species labelled as negatively charged gold $\mathrm{Au}^{-}$or $\mathrm{Au}^{0}$ in bimetallic particles. The distribution of all these species strongly depended on the chemical composition of the materials. Zirconium was present in one oxidation state, +4 , characterized by BE at approximately $182 \mathrm{eV}$ (in the range of 182.1$183.0 \mathrm{eV}$ for the supports and 181.4-183.6 eV for the copper 

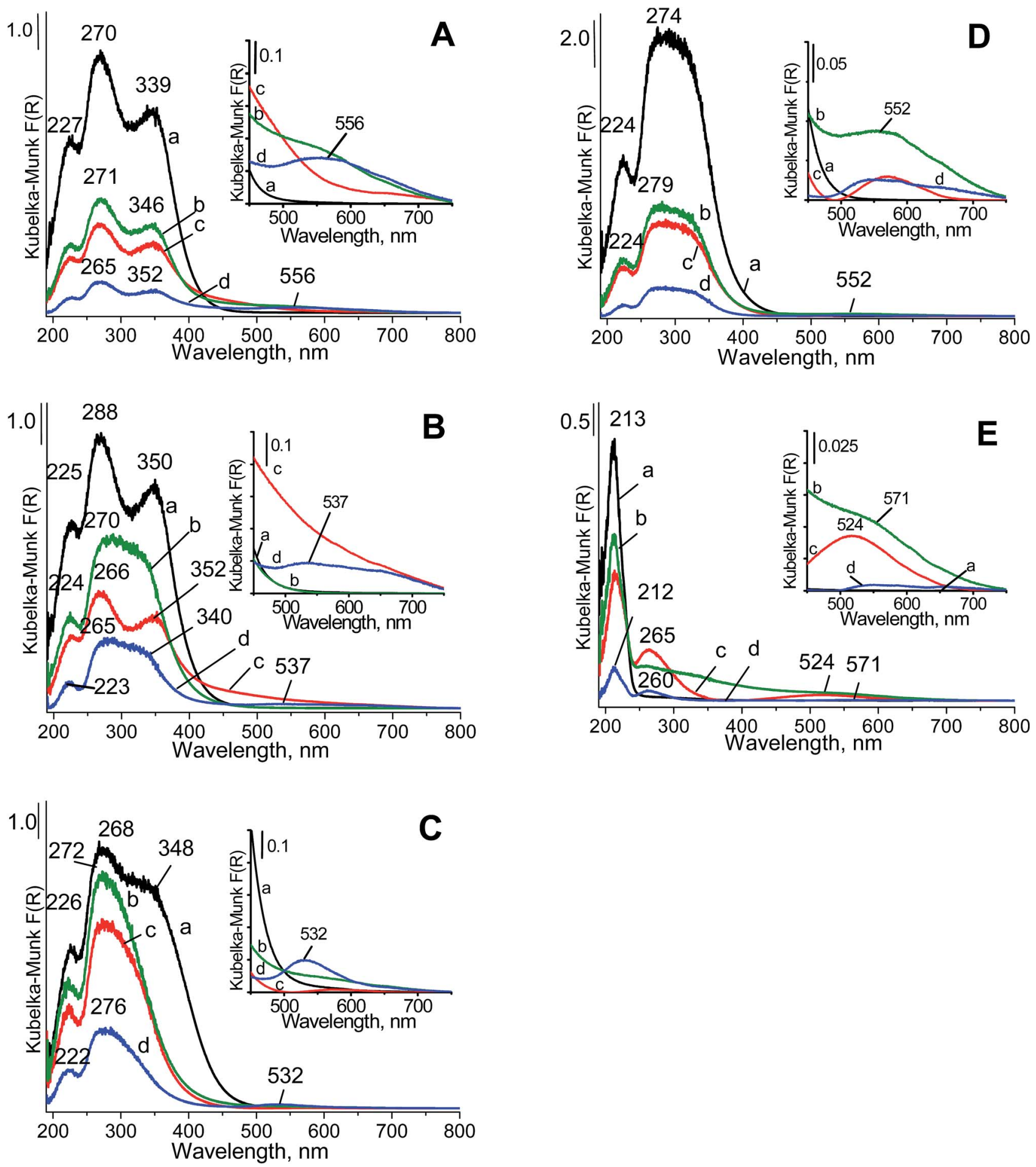

Fig. 3 UV-vis spectra of catalysts: [A] (a) $\mathrm{CeO}_{2} ;$ (b) $\mathrm{Au} / \mathrm{CeO}_{2} ;$ (c) $\mathrm{Cu} / \mathrm{CeO}_{2}$; (d) $\mathrm{CuAu} / \mathrm{CeO}{ }_{2}$; [B] (a) $\mathrm{CeZrO}$ (2 : 1); (b) $\mathrm{Au} / \mathrm{CeZrO}$ (2: 1); (c) $\mathrm{Cu}$ /

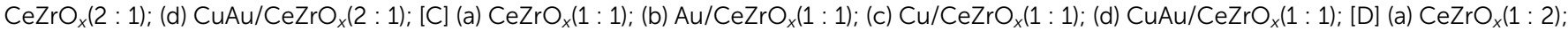
(b) $\mathrm{Au} / \mathrm{CeZrO}_{x}\left(1\right.$ : 2); (c) $\mathrm{Cu} / \mathrm{CeZrO}_{x}(1: 2)$; (d) $\mathrm{CuAu} / \mathrm{CeZrO}$ (1 : 2); [E] (a) $\mathrm{ZrO}_{2}$; (b) $\mathrm{Au} / \mathrm{ZrO} \mathrm{Z}_{2}$; (c) $\mathrm{Cu} / \mathrm{ZrO} \mathrm{Z}_{2}$ and (d) $\mathrm{CuAu} / \mathrm{ZrO}$.

and/or gold modified samples). This indicated the interaction between the elements in mixed oxides and with gold and copper species loaded on the surface of the supports. The highest interaction seems to occur between copper, gold and zirconia as evidenced from the very low BE for the samples based on pure zirconia.
There is a domination of $\mathrm{Ce}^{4+}$ on the surface of all mixed cerium-zirconium oxides (Table 4). The increase in zirconium content in the mixed oxides slightly increased the amount of $\mathrm{Ce}^{4+}$ from 78 to $85 \%$. Modification of the supports with gold affected the distribution of cerium species. A significant increase in the content of cerium in the lower oxidation state 
Table 3 Binding energies of zirconium, copper and gold species - data from XPS

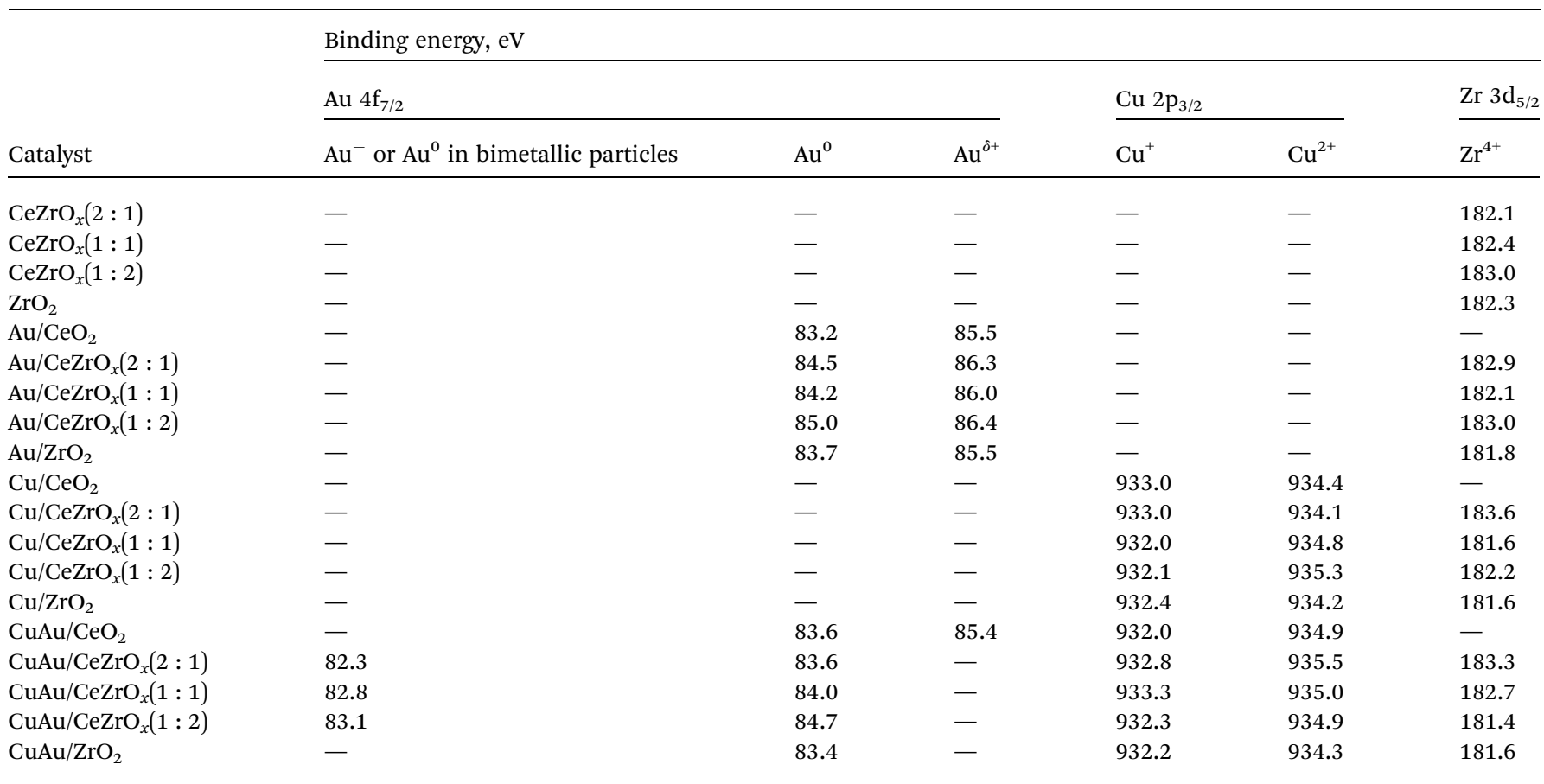

Table 4 Distribution of cerium, copper and gold species calculated from XP spectra

\begin{tabular}{|c|c|c|c|c|c|c|c|}
\hline \multirow[b]{2}{*}{ Catalyst } & \multicolumn{2}{|c|}{$\begin{array}{l}\text { Distribution of Ce } \\
\text { species, \% }\end{array}$} & \multicolumn{2}{|c|}{$\begin{array}{l}\text { Distribution of } \mathrm{Cu} \\
\text { species, \% }\end{array}$} & \multicolumn{3}{|c|}{ Distribution of $\mathrm{Au}$ species, \% } \\
\hline & $\mathrm{Ce}^{3+}$ & $\mathrm{Ce}^{4+}$ & $\mathrm{Cu}^{+}$ & $\mathrm{Cu}^{2+}$ & $\begin{array}{l}\mathrm{Au}^{-} \text {or } \mathrm{Au}^{0} \text { in } \\
\text { bimetallic particles }\end{array}$ & $\mathrm{Au}^{0}$ & $\mathrm{Au}^{\delta+}$ \\
\hline $\mathrm{CeZrO}_{x}(2: 1)$ & 22 & 78 & - & - & - & - & - \\
\hline $\mathrm{CeZrO}_{x}(1: 1)$ & 21 & 79 & - & - & - & - & - \\
\hline $\mathrm{CeZrO}_{x}(1: 2)$ & 15 & 85 & - & - & - & - & - \\
\hline $\mathrm{Au} / \mathrm{CeO}_{2}$ & 29 & 71 & - & - & & 76 & 24 \\
\hline $\mathrm{Au} / \mathrm{CeZrO}_{x}(2: 1)$ & 20 & 80 & - & - & - & 63 & 37 \\
\hline $\mathrm{Au} / \mathrm{CeZrO}_{x}(1: 1)$ & 24 & 76 & - & - & - & 61 & 39 \\
\hline $\mathrm{Au} / \mathrm{CeZrO}_{x}(1: 2)$ & 34 & 66 & - & - & - & 61 & 39 \\
\hline $\mathrm{Au} / \mathrm{ZrO}_{2}$ & - & - & - & - & - & 89 & 11 \\
\hline $\mathrm{Cu} / \mathrm{CeO}_{2}$ & 40 & 60 & 58 & 42 & - & - & - \\
\hline $\mathrm{Cu} / \mathrm{CeZrO}_{x}(2: 1)$ & 20 & 80 & 55 & 46 & - & - & - \\
\hline $\mathrm{Cu} / \operatorname{CeZrO}_{x}(1: 1)$ & 44 & 56 & 89 & 11 & - & - & - \\
\hline $\mathrm{Cu} / \mathrm{CeZrO}_{x}(1: 2)$ & 25 & 75 & 42 & 58 & - & - & - \\
\hline $\mathrm{Cu} / \mathrm{ZrO}_{2}$ & - & - & 85 & 15 & - & - & - \\
\hline $\mathrm{CuAu} / \mathrm{CeO}_{2}$ & 23 & 77 & 83 & 17 & - & 96 & 4 \\
\hline $\mathrm{CuAu} / \mathrm{CeZrO}_{x}(2: 1)$ & 29 & 71 & 77 & 23 & 39 & 61 & - \\
\hline $\mathrm{CuAu} / \mathrm{CeZrO}_{x}(1: 1)$ & 18 & 82 & 91 & 9 & 19 & 81 & - \\
\hline $\mathrm{CuAu} / \mathrm{CeZrO}_{x}(1: 2)$ & 11 & 89 & 34 & 66 & 67 & 33 & - \\
\hline $\mathrm{CuAu} / \mathrm{ZrO}_{2}$ & - & - & 86 & 14 & - & 100 & - \\
\hline
\end{tabular}

(+3) was noted in $\mathrm{Au} / \mathrm{CeZrO}_{x}(1: 2)$ (from 15 to 34\%), suggesting the reduction of cerium cations during the modification with auric acid and urea. This reduction of $\mathrm{Ce}^{4+}$ was paralleled by formation of more oxidized gold species (61\% of $\mathrm{Au}^{\delta+}$ ).

The distribution of cerium cations on the surface of the supports was also influenced by modification with copper and both copper and gold species. It is difficult to note a simple relationship between the oxidation state of cerium and the chemical composition of the catalysts. However, there is no doubt that copper and gold loading influence the oxidation state of cerium. The reducing environment of the vacuum may contributed in degree of cerium(Iv) reduction.

Gold loaded on ceria, zirconia and cerium-zirconium mixed oxides was characterized in the XP spectra by the two spin-orbit components $\mathrm{Au} 4 \mathrm{f}_{7 / 2}$ and $\mathrm{Au} 4 \mathrm{f}_{5 / 2}$, separated and composed of two doublets attributed to different gold species (examples in Fig. S3†), corresponding to $\mathrm{Au}^{0}$ and $\mathrm{Au}^{\delta+}$ species (Table 3) ${ }^{58-63} \mathrm{It}$ is difficult to distinguish different oxidation states in cationic 
gold on the basis of BE. The value between $85 \mathrm{eV}$ and $86 \mathrm{eV}$ can be attributed to +1 oxidation state whereas the values above $86 \mathrm{eV}$ can characterized the charge transfer in cationic gold with higher oxidation state. Therefore $+\delta$ oxidation state is noted in this work, where $\delta \geq 1$. The BE value was influenced by the chemical composition of the supports. For metallic gold species, the BE changed from $83.2 \mathrm{eV}$ to $85.0 \mathrm{eV}$. The lowest values of $\mathrm{BE}$ were observed if gold was loaded on pure ceria (83.3 $\mathrm{eV}$ ) and zirconia (83.7 eV). These energies are lower than typical of bulk metallic gold $(84.0 \mathrm{eV}) .{ }^{64}$ The lowering of BE can be caused by a decrease in the size of gold particles, as noted in ref. 62.

All monometallic (gold) catalysts presented the domination of metallic gold. The distribution of metallic and cationic gold species was determined by the chemical composition of the supports. The higher amount of metallic gold was noted on pure zirconia and ceria (Table 4). More cationic gold species $\left(\mathrm{Au}^{\delta+}\right)$ were formed on mixed ceria-zirconia supports. Generally, the $\mathrm{Au}^{\delta+}$ species were present mainly on the surface of monometallic ( $\mathrm{Au} /$ support) samples. In bimetallic ( $\mathrm{Cu}-\mathrm{Au} /$ support) materials, cationic gold was observed only on pure ceria but in a very small quantities. The introduction of copper not only decreased or removed cationic gold species, it also increased the amount of metallic gold on pure ceria and zirconia and on mixed ceria-zirconia supports, the latter with enhanced shielding of the core hole. This finding indicates that the existence of reducible copper species in copper-gold catalysts is responsible for enhanced core-hole shielding. ${ }^{12}$ The species characterized by $\mathrm{BE}$ below $83 \mathrm{eV}$ were interpreted by some authors as negatively charged gold on different supports, e.g. ref. 46, 52 and 58. The XP spectra of bimetallic samples in the $\mathrm{Au} 4 \mathrm{f}$ range were characterized by two doublets (with the exception of $\mathrm{CuAu} / \mathrm{ZrO}_{2}$ ), which origin depends on the nature of the supports. In the case of copper-gold loaded on ceria, the species characterized by $\mathrm{BE} 4 \mathrm{f}_{7 / 2}$ of 83.6 and $85.4 \mathrm{eV}$ were attributed to $\mathrm{Au}^{0}$ and $\mathrm{Au}^{\delta+}$, respectively.

The XP spectra of bimetallic samples in the Au $4 \mathrm{f}$ range were characterized by two doublets (with the exception of $\mathrm{CuAu}$ / $\mathrm{ZrO}_{2}$ ), which origin depends on the nature of the supports. In the case of copper-gold loaded on ceria, the species characterized by $\mathrm{BE} 4 \mathrm{f}_{7 / 2}$ of 83.6 and $85.4 \mathrm{eV}$ were attributed to $\mathrm{Au}^{0}$ and $\mathrm{Au}^{\delta+}$, respectively.

On the mixed cerium-zirconium oxides, besides pure metallic gold ( $\mathrm{BE}$ in the range of $83.6-84.7 \mathrm{eV}$ ) a $\mathrm{Au} 4 \mathrm{f}_{7 / 2}$ peak at lower $\mathrm{BE}$ (the range of $\sim 82-83 \mathrm{eV}$ ) was observed. $\mathrm{CuAu} / \mathrm{ZrO}_{2}$ contained only metallic gold species (the peak at $83.4 \mathrm{eV}$ ).

The XPS bands covering the range of $83-85 \mathrm{eV}$ is consistent with $\mathrm{a} \mathrm{Au}^{0}$ oxidation state. ${ }^{62,63}$ The lower binding energy observed for $\mathrm{Au}^{0} 4 \mathrm{f}_{7 / 2}$ in the copper-gold catalysts than in monometallic gold catalysts can be attributed to the smaller particle size. ${ }^{63}$ The lower coordination of gold atoms causes this band to shift, ${ }^{65,66}$ in agreement with the STEM-EDXS results (Fig. S2 $\dagger$ ). As concerns the appearance of XP bands in the range of $\sim 82-83 \mathrm{eV}$ they should be attributed to the changes in electronic structure of the system and core-hole shielding.

The $\mathrm{BE}$ of $\mathrm{Cu} 2 \mathrm{p}$ peaks were assigned based on the literature, ${ }^{67,68}$ to $\mathrm{Cu}^{+}$(in the range of $932.0-933.0 \mathrm{eV}$ ) and $\mathrm{Cu}^{2+}(934.1-$
935.5 eV). All samples containing copper (monometallic and bimetallic), except for $\mathrm{Cu} / \mathrm{CeZrO}_{x}(1: 2)$ and $\mathrm{CuAu} / \mathrm{CeZrO}_{x}(1: 2)$, exhibited the domination of surface $\mathrm{Cu}^{+}$cations. Notably, the $\mathrm{Cu}^{+}$ content increased in the presence of gold species (except for $\left.\mathrm{CuAu} / \mathrm{CeZrO}_{x}(1: 2)\right)$. The lower amount of surface $\mathrm{Cu}^{+}$in $\mathrm{CuAu} /$ $\mathrm{CeZrO}_{x}(1: 2)$ compared to monometallic copper catalyst was accompanied by the growth of gold peaks with BE between 82 and $83 \mathrm{eV}$ indicative of direct interaction between gold and copper.

\subsection{Temperature-programmed reduction by hydrogen $\left(\mathrm{H}_{2^{-}}\right.$ TPR)}

All components of the catalysts can be reduced by hydrogen. An analysis of gold and copper reduction was made in the temperature range between 373 and $723 \mathrm{~K}$ (Fig. 4). In this temperature range the peaks coming from the reduction of cationic gold respectively cationic copper in the 400 to $480 \mathrm{~K}$ range are well distinguished. The reduction of cationic gold and copper in bimetallic samples could not be strictly distinguished because the range of the reduction temperatures for both metals is similar and the two metals may affect each other's reduction behavior.

Fig. 4A-E shows the TPR profiles of monometallic gold, copper and bimetallic copper-gold systems loaded on different supports. For simplicity, only the most intense peak, from the reduction of cationic gold and/or copper in the range at ca. 400$480 \mathrm{~K}$, is considered. The position of this peak was almost independent of the composition of modifiers (only copper, only gold or both copper and gold) on ceria (Fig. 4A) or zirconia (Fig. 4E). For mixed cerium-zirconium oxide supports, the reduction temperatures of cationic gold and copper species were determined by the composition of the supports. With increasing zirconium content in the support, the reduction temperatures of copper and gold species were more separated, and generally, they decreased with the increasing content of zirconia in the mixed oxides used. The lowest reduction temperatures were characteristic of metals loaded on $\mathrm{CeZrO}_{x}(1: 2)$ (Fig. 4F).

This phenomenon indicated a stronger interaction of cationic gold and copper with mixed cerium-zirconium oxides, particularly if the zirconium content was higher. The promoting effect of zirconium was shown in the literature ${ }^{69,70}$ Notably, the loading of both copper and gold on the mixed oxides caused a significant decrease in the reduction temperature, particularly evident for $\operatorname{CeZrO}_{x}(1: 2)$ (a decrease to $398 \mathrm{~K}$ ). Such a high decrease in the reduction temperature must be influenced not only by the interaction of modifiers with mixed ceria-zirconium oxides but also by the interaction between gold and copper. In the catalysts modified with copper, $\mathrm{Cu}^{2+}$ loaded on oxides of transition metals (ceria, zirconia or mixed cerium-zirconium oxides) was reduced to metallic copper $\mathrm{Cu}^{0}$ below $473 \mathrm{~K}$ (in the case of smaller particles of copper(II) oxide) and at approximately $523 \mathrm{~K}$ (in the case of larger particles of copper(II) oxide). ${ }^{71}$ The peaks around $450-475 \mathrm{~K}$ can be ascribed mainly to the reduction of copper(II) oxide particles having little or no interaction with the support. This assignment is in agreement with literature data. ${ }^{72,73}$ 

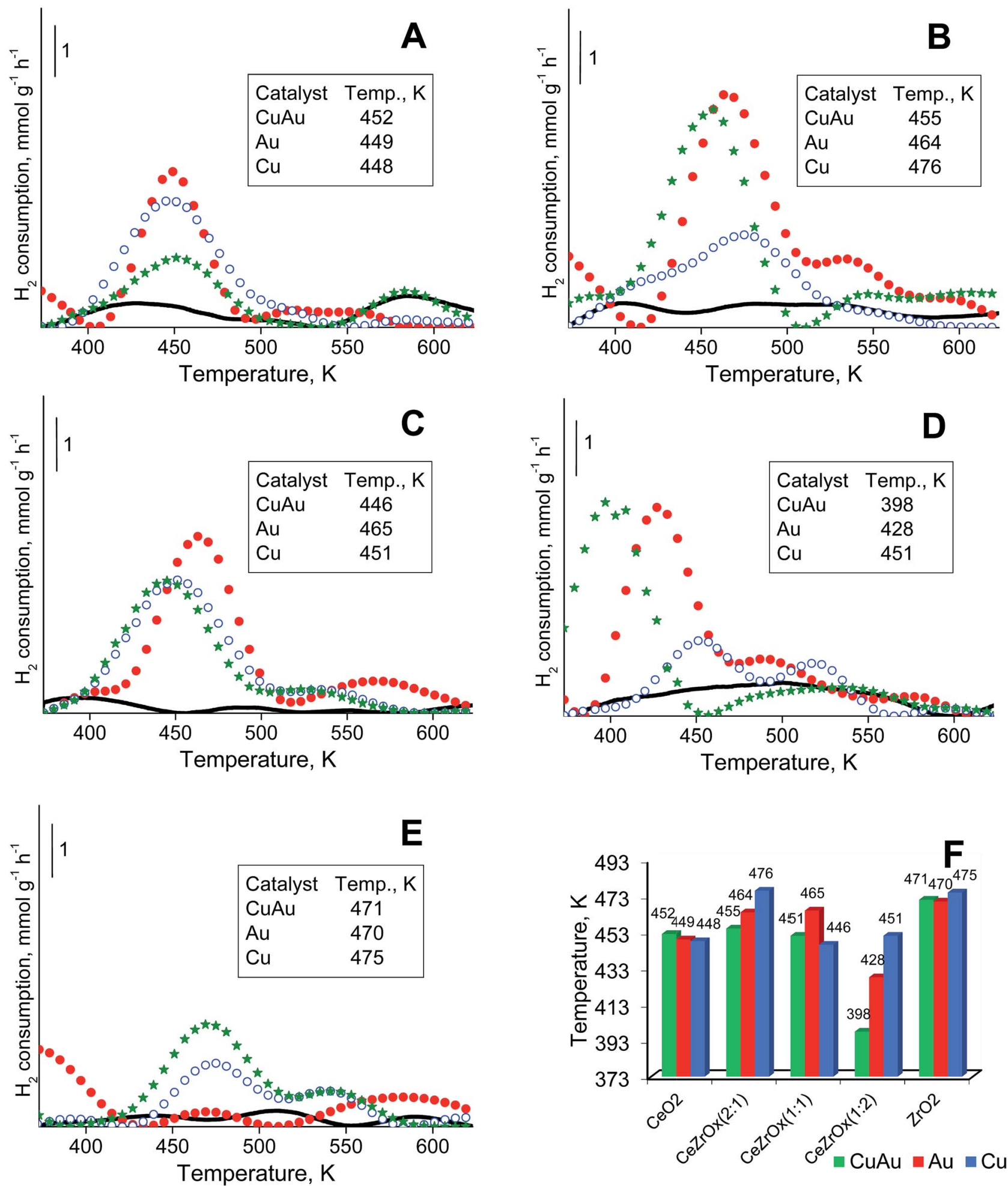

Fig. 4 TPR profiles performed for catalysts supported on: $[\mathrm{A}] \mathrm{CeO}_{2}, \mathrm{Au} / \mathrm{CeO}_{2}, \mathrm{Cu} / \mathrm{CeO}_{2}$ and $\mathrm{CuAu} / \mathrm{CeO} 2,[\mathrm{~B}] \mathrm{CeZrO} \times(2: 1), \mathrm{Au} / \mathrm{CeZrO} \times(2: 1), \mathrm{Cu} /$ $\mathrm{CeZrO}_{x}(2: 1)$ and $\mathrm{CuAu}_{\mathrm{CeZrO}}(2: 1),[\mathrm{C}] \mathrm{CeZrO}_{x}(1: 1), \mathrm{Au} / \mathrm{CeZrO}{ }_{x}(1: 1), \mathrm{Cu} / \mathrm{CeZrO}_{x}(1: 1)$ and $\mathrm{CuAu} / \mathrm{CeZrO}{ }_{x}(1: 1),[\mathrm{D}] \mathrm{CeZrO} \mathrm{C}_{x}(1: 2), \mathrm{Au} /$ $\mathrm{CeZrO}_{x}(1: 2), \mathrm{Cu} / \mathrm{CeZrO}_{x}(1: 2)$ and $\mathrm{CuAu} / \mathrm{CeZrO}{ }_{x}(1: 2),[\mathrm{E}] \mathrm{ZrO}, \mathrm{Au} / \mathrm{ZrO}_{2}, \mathrm{Cu} / \mathrm{ZrO}_{2}$ and $\mathrm{CuAu} / \mathrm{ZrO}_{2}$, where supports were marked as black solid line ( $(-)$, Au catalysts - red dotted line (○○), Cu catalysts - blue dotted line $(\bigcirc \bigcirc \bigcirc), \mathrm{Cu}-\mathrm{Au}$ catalysts - green stars line ( $\star \star \star)$, [F] comparison of the maximum hydrogen consumption during TPR achieved by catalysts modified with Au and/or Cu.

The temperatures of bulk copper(II) oxide reduction were reported between 473 and $573 \mathrm{~K}^{70,74}$ According to the literature $^{75-82}$ the reducibility of copper(II) oxide loaded on ceria is promoted in the presence of hydrogen. Two reduction peaks in the region described above has been reported by several authors. $^{75,77,78,82}$ These peaks were attributed to the reduction of 
copper(II) oxide clusters. The first peak, at a lower temperature, was assigned to nanoclusters strongly interacting with ceria. The second peak, at a higher temperature, was attributed to copper(II) oxide species which were more like bulk oxide, less experiencing with ceria. The different interaction can be explained by the different particle size, the smaller the particle diameter, the higher the extent of interaction and therefore the easier reducibility. ${ }^{\mathbf{8 1}}$

It is noteworthy that TPR profiles of $\mathrm{CuAu} / \mathrm{CeO}_{2}$ and ceria samples (Fig. 4A) show a reduction peak at around $573 \mathrm{~K}$. This indicates that in the case of mesoporous ceria, pure ceria particles can be reduced at around $573 \mathrm{~K}$. In the case of Ce- $\mathrm{Zr}$ oxides and pure zirconia, this peak is observed in the samples modified with copper and gold (except $\mathrm{CuAu} / \mathrm{CeZrO}_{x}(1: 2)$, Fig. 4D). It is not observed on the TPR profiles of supports (oxides) (Fig. 4B, C and E). The synergistic interaction between cerium (in the mixed oxides), zirconium (in the case of pure zirconia as support), gold (as $\mathrm{Au}^{\delta+}$ ) and copper $\left(\mathrm{as} \mathrm{Cu}^{2+}\right.$ ) species leads to lower a reduction temperature of copper. ${ }^{83}$

Hydrogen consumption above $573 \mathrm{~K}$ results from reduction of bulk copper(II) oxide. The temperatures of maximum hydrogen consumption observed in Fig. 4 were significantly lower than that of bulk copper(II) oxide. If small copper(II) oxide particles were loaded on ceria, ${ }^{76,79-81}$ this support could promote their reduction below $573 \mathrm{~K}$. The reduction of copper oxide clusters, strongly interacting with ceria, occurred in the range 398-448 K, and larger copper(II) oxide particles, non-associated with ceria, were reduced at approximately $473 \mathrm{~K}^{78}$

Copper(II) oxide-ceria catalysts revealed two maxima of hydrogen consumption: in the range of 423-441 K, assigned to small copper(II) oxide crystallites in contact with ceria, and in the range of 453-498 $\mathrm{K}$, attributed to larger copper(II) oxide particles not in close contact with ceria. ${ }^{76,77} \mathrm{~A}$ comparison of temperatures of maximum hydrogen consumption over coppergold and copper catalysts led to a conclusion that in bimetallic copper-gold samples based on the mixed cerium-zirconium oxides, copper or gold were reduced at lower temperatures than over the analogous monometallic catalysts. This finding confirmed the interaction between copper and gold.

\subsection{Catalytic activity - glycerol oxidation in the liquid phase}

The challenge in the development of efficient oxidation catalysts is to obtain high activity, selectivity, and stability. Activity and selectivity of gold catalysts in glycerol oxidation are influenced by the nature of the support, which determines the species formed on the surface ${ }^{\mathbf{3 0 , 8 4 , 8 5}}$ and the presence of other catalytically active components (e.g. palladium-gold, platinumgold).$^{13,86}$ Catalytic glycerol oxidation was performed by stirring at different rates to find the conditions in which diffusion had the least influence on the catalytic reaction (Tables S1 and S2 $\dagger$ ). The conversion of glycerol increased up to $1000 \mathrm{rpm}$. Therefore, further experiments were carried out using this stirring speed.

Table 5 shows the results of the catalytic oxidation of glycerol at $333 \mathrm{~K}$ in a basic aqueous solution under pure oxygen for monometallic and bimetallic catalysts. Copper-gold catalysts were definitely more active than monometallic catalysts under the same reaction conditions. The monometallic catalysts yielded primarily gaseous products. Changes in the copper and gold dispersion and electronic states, relative to those in monometallic ones, play a crucial role in increasing the catalyst activity and selectivity to glyceric acid. ${ }^{87,88}$ Increase of glycerol conversion with increase of gold dispersion and decrease in selectivity to glyceric acid for small mean gold particle size (e.g. $2.7 \mathrm{~nm}$ in ref. 88) were observed. Here, the dispersion of gold and glycerol conversion were higher for bimetallic (gold-

Table 5 The results of glycerol oxidation at $333 \mathrm{~K}^{a}$

\begin{tabular}{|c|c|c|c|c|c|c|c|c|}
\hline \multirow[b]{2}{*}{ Catalyst } & \multirow[b]{2}{*}{ Conv., \% } & \multicolumn{6}{|c|}{ Selectivity, \% } & \multirow[b]{2}{*}{$\mathrm{TOF}^{h}, \mathrm{~h}^{-1}$} \\
\hline & & $\mathrm{TA}^{b}$ & $\operatorname{GLA}^{c}$ & $\mathrm{LA}^{d}$ & $\mathrm{GCA}^{e}$ & $\mathrm{FA}^{f}$ & Gaseous products ${ }^{g}$ & \\
\hline $\mathrm{Cu} / \mathrm{CeO}_{2}$ & 19 & Traces & 7 & - & 2 & 1 & 90 & - \\
\hline $\mathrm{Cu} / \mathrm{CeZrO}_{x}(2: 1)$ & 31 & - & 9 & - & 2 & 1 & 88 & - \\
\hline $\mathrm{Cu} / \operatorname{CeZrO}_{x}(1: 1)$ & 35 & Traces & 5 & - & 1 & Traces & 94 & - \\
\hline $\mathrm{Cu} / \mathrm{CeZrO}_{x}(1: 2)$ & 28 & Traces & 7 & - & 1 & 1 & 91 & - \\
\hline $\mathrm{Cu} / \mathrm{ZrO}_{2}$ & 28 & Traces & 7 & - & 2 & 1 & 90 & - \\
\hline $\mathrm{Au} / \mathrm{CeO}_{2}$ & 40 & Traces & 19 & 1 & - & 1 & 79 & 77 \\
\hline $\mathrm{Au} / \mathrm{CeZrO}_{x}(2: 1)$ & 35 & Traces & 10 & Traces & - & Traces & 90 & 63 \\
\hline $\mathrm{Au} / \mathrm{CeZrO}_{x}(1: 1)$ & 35 & Traces & 6 & - & - & - & 94 & 71 \\
\hline $\mathrm{Au} / \mathrm{CeZrO}_{x}(1: 2)$ & 15 & Traces & 7 & - & - & - & 93 & 30 \\
\hline $\mathrm{Au} / \mathrm{ZrO}_{2}$ & 30 & Traces & 5 & - & - & - & 95 & 98 \\
\hline $\mathrm{CuAu} / \mathrm{CeO}_{2}$ & 72 & - & 68 & - & 17 & 16 & - & 667 \\
\hline $\mathrm{CuAu} / \mathrm{CeZrO}_{x}(2: 1)$ & 83 & - & 65 & - & 14 & 21 & - & 838 \\
\hline $\mathrm{CuAu} / \mathrm{CeZrO}_{x}(1: 1)$ & 80 & - & 79 & - & 7 & 14 & - & 618 \\
\hline $\mathrm{CuAu} / \mathrm{CeZrO}_{x}(1: 2)$ & 87 & - & 68 & - & 6 & 11 & 15 & 901 \\
\hline $\mathrm{CuAu} / \mathrm{ZrO}_{2}$ & 80 & - & 70 & - & 11 & 16 & 3 & 1236 \\
\hline
\end{tabular}

${ }^{a}$ Reaction conditions: $5 \mathrm{~h}, 1000 \mathrm{rpm}, 6 \mathrm{~atm}$ of oxygen, $\mathrm{NaOH} / \mathrm{glycerol}=2,15.00 \mathrm{~g}$ of water, $0.120 \mathrm{~g}$ of NaOH, $0.138 \mathrm{~g}$ of glycerol, $0.0300 \mathrm{~g}$ of catalyst. ${ }^{b} \mathrm{TA}$ - tartronic acid. ${ }^{c}$ GLA - glyceric acid. ${ }^{d} \mathrm{LA}$ - lactic acid. ${ }^{e} \mathrm{GCA}$ - glycolic acid. ${ }^{f} \mathrm{FA}$ - formic acid. ${ }^{g} \mathrm{Gaseous}$ products - $\mathrm{CO}_{2}$ and other gases.

${ }^{h}$ TOF was calculated as the number of glycerol moles reacted on one mole of gold per one hour (calculated from the conversion obtained after $30 \mathrm{~min}$ of the reaction in the case of $\mathrm{Cu}-\mathrm{Au}$ catalysts and after $300 \mathrm{~min}$ in the case of Au catalyst). 
copper) catalysts than for monometallic ones. However, contrary to the findings described in literature ${ }^{87,88}$ for gold catalysts, bimetallic catalysts in this work presented the higher selectivity to glyceric acid despite the small mean gold particle size $(<2.7 \mathrm{~nm})$. All copper-gold catalysts were selective primarily towards glyceric acid. Low selectivities to other oxidation products, such as lactic, oxalic, tartronic, glycolic, and formic acids were observed. The oxidation of glycerol to glyceric acid under basic conditions on copper-gold catalysts proceeds via the initial formation of glyceraldehyde, which is rapidly oxidized to glyceric acid. ${ }^{14}$ Tartronic, C2, and C1 acids indicate over-oxidation or transformation of glyceric acid.

In the bimetallic system, gold and copper were in close proximity, therefore, the interaction between them made the interaction with reagents more effective. The activity and selectivity of copper-gold catalysts were also influenced by the chemical composition of the supports. The highest selectivity to glyceric acid was observed for $\mathrm{CuAu} / \mathrm{CeZrO}_{x}(1: 1)$. In this catalyst, the microporosity was negligible, and therefore, the diffusion of the primary product, glyceric acid, was easy, preventing capturing the intermediates and preventing over-oxidation.

Among bimetallic catalysts TOF was the highest on $\mathrm{CuAu} /$ $\mathrm{ZrO}_{2}$ than on the rest of bimetallic catalysts (Table 5). This catalyst had the smallest gold particles (average size $1.6 \mathrm{~nm}$ ), exclusively metallic gold species and a domination of $\mathrm{Cu}^{+}$ cations. Thus, such metallic species will be considered in the drawing of the reaction pathway at the end of this section. The best gold catalysts based on carbon or different metal oxides described in the literature as catalysts attractive for glycerol oxidation exhibited similar or lower TOF than $\mathrm{CuAu} / \mathrm{ZrO}_{2}$. Table $33 \dagger$ collects the best TOF data from the literature $\mathbf{2 8 , 6 2 , 8 9 , 9 0}^{\mathbf{2}}$ in which the conditions of glycerol oxidation were similar to those applied in this work. The bimetallic catalysts achieved higher TOFs than monometallic gold catalysts (Table 5), explained by the crucial role of the interaction between gold and copper in the activation of glycerol adsorption and then its oxidation.

3.6.1. Effect of the reaction temperature. To obtain further information on the performance of the catalysts, oxidation experiments were conducted at different temperatures. The increase in the glycerol conversion was significant for all copper-gold catalysts when the reaction temperature increased from 333 to $363 \mathrm{~K}$. At both reaction temperatures glyceric acid was the main product. The increase in the reaction temperature led to higher yields of lactic acid, as a result of the dehydration of glyceric acid molecules (Table S4 $\dagger$ ). At $333 \mathrm{~K}$, glyceric acid transformed to formic acid and glycolic acid (Scheme 1).

At $363 \mathrm{~K}$, the monometallic gold catalysts showed high glycerol conversion on $\mathrm{Au} / \mathrm{CeO}_{2}$, but much lower on $\mathrm{Au} / \mathrm{ZrO}_{2}$, yielding selectivity to glyceric acid and lactic acid and to a relatively small amount of formic acid (Table $\mathrm{S} 1 \dagger$ ). On copper catalysts (Table $\mathrm{S} 2 \dagger$ ), in addition to glyceric acid, glycolic and formic acids were formed in high yields at $363 \mathrm{~K}$. This behavior indicated that copper species were responsible for the dehydration of the primary product, glyceric acid, whereas in the presence of gold-active centers, glyceric acid was formed and transformed to lactic acid at a higher temperature.

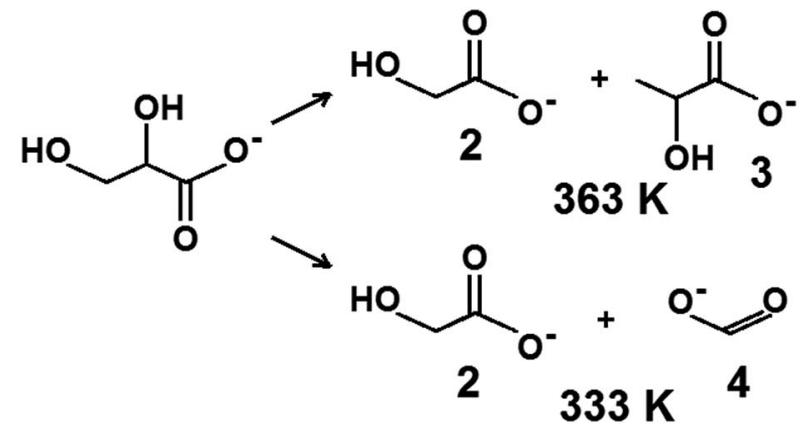

Scheme 1 Main products of glycerol oxidation over $\mathrm{Cu}-\mathrm{Au}$ catalysts at basic condition ( $\mathrm{pH}=14)$ at $333 \mathrm{~K}$ and $363 \mathrm{~K}$ where (1) glycerolate, (2) glycolate, (3) lactate, (4) formate.

3.6.2. Changes in activity and selectivity and catalytic stability. A comparison of glycerol conversion (Fig. 5) and the changes in oxygen consumption during the reaction of glycerol oxidation (Fig. S4 $\dagger$ ) showed that $\mathrm{CuAu} / \mathrm{CeZrO}_{x}(1: 2)$ exhibited the highest conversion in glycerol oxidation at $333 \mathrm{~K}$ after $5 \mathrm{~h}$, at $1000 \mathrm{rpm}$. Over this catalyst, the oxygen consumption in the reaction was the smallest. After $150 \mathrm{~min}$ of the reaction over cerium-zirconium oxides modified with copper and gold, the oxygen consumption was smaller than over $\mathrm{CuAu} / \mathrm{CeO}_{2}$ and $\mathrm{CuAu} / \mathrm{ZrO}_{2}$.

Between 30 and 300 min reaction, the molar ratio oxygen: glycerol was always higher than 3.5 for all copper-gold catalysts, but this parameter changed linearly from 7 after 30 min to 21 after $300 \mathrm{~min}$ (Fig. $\mathrm{S} 4 \dagger$ ). At the beginning, the molar ratio oxygen : glycerol increased over all bimetallic catalysts, but after $180 \mathrm{~min}$, for $\mathrm{CuAu} / \mathrm{CeO}_{2}$ and $\mathrm{CuAu} / \mathrm{CeZrO}_{x}(2: 1)$, this value decreased from 6 to 4 and from 16 to 14, respectively.

The reaction profiles (Fig. 5) indicated that after $2 \mathrm{~h}$ of the reaction, $c a$. $60-80 \%$ of glycerol was converted; then, the conversion leveled off. The high selectivity to glyceric acid in the initial stages of the reaction indicated that it was formed in the first step of the reaction. Formic and glycolic acid were also detected, but the selectivity to these compounds increased slowly during the reaction and decreased when the concentration of carbon dioxide increased.

The most active bimetallic catalysts were stable and glycerol conversion in the second cycle of the reaction was not considerably changed. It is characteristic that at constant activity, the selectivity to glyceric acid increased in the second reaction cycle performed over bimetallic catalysts based on zirconia and cerium-zirconium mixed oxides rich in zirconium. This phenomenon suggested changes in the catalyst surface during reaction.

The possibility of reusing catalysts without the loss of activity is very important. Fig. 6 shows the results of the experiments in which the catalysts were reused in the reaction at $333 \mathrm{~K}$ and a stirring speed of $1000 \mathrm{rpm}$. The catalyst used in the first reaction cycle was recovered by decantation of the solvent after the reaction and was reused without any washing or drying.

The increase in glyceric acid selectivity in the second cycle was highly desirable. The highest glycerol conversion was 

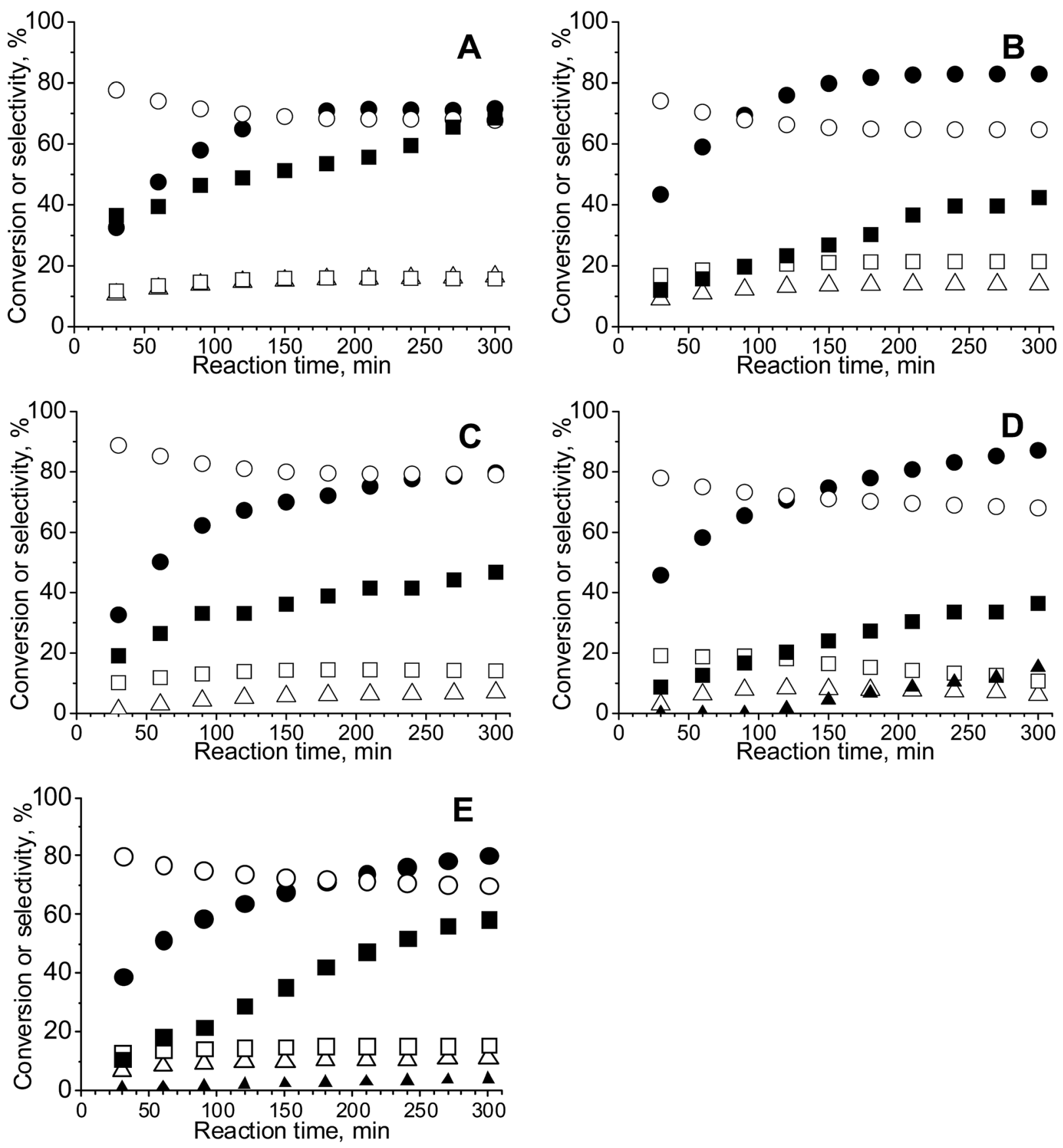

Fig. 5 Conversion and selectivity during the reaction of glycerol oxidation at $333 \mathrm{~K}$ for $5 \mathrm{~h}$ at $1000 \mathrm{rpm}$ over bimetallic catalysts: (A) - CuAu/ $\mathrm{CeO}_{2} ;(\mathrm{B})-\mathrm{CuAu} / \mathrm{CeZrO}_{x}(2: 1) ;(\mathrm{C})-\mathrm{CuAu} / \mathrm{CeZrO}_{x}(1: 1) ;(\mathrm{D})-\mathrm{CuAu} / \mathrm{CeZrO}_{x}(1: 2)$ and (E) $-\mathrm{CuAu} / \mathrm{ZrO}{ }_{2}$, where: - conversion; selectivity to: $\bigcirc$ - glyceric acid; $\Delta$ - glycolic acid; $\square$ - formic acid; $\boldsymbol{\Delta}$ - gaseous products; $\mathbf{\square}$ - oxygen consumption.

achieved by $\mathrm{CuAu} / \mathrm{CeZrO}_{x}(1: 2)$ in the first cycle $(87 \%)$, whereas the highest selectivity to glyceric acid was reached on $\mathrm{CuAu}$ / $\mathrm{ZrO}_{2}$ in the second cycle (83\%). Notably, CuAu/CeZrO ${ }_{x}(1: 2)$ material contained the lowest content of $\mathrm{Cu}^{+}$species and the highest amount of bimetallic particles. The increase of GLA selectivity was considered in the context of metal leaching during the first reaction. Table S5 $\uparrow$ shows the amount of copper and gold in the catalysts after the second reaction. It is clear that zirconium strongly hold copper species and therefore leaching of copper did not occur for $\mathrm{CuAu} / \mathrm{CeZrO}_{x}(1: 2)$. In contrast, for this sample gold was partially leached. This behaviour led to the increase of $\mathrm{Cu}: \mathrm{Au}$ molar ratio which caused the increase of selectivity to GLA. On the basis of the results obtained within this work the reaction pathway of the glycerol oxidation to glyceric acid performed on bimetallic ( $\mathrm{Cu}-\mathrm{Au})$ catalysts based on metal oxides used in this work was proposed (Scheme 2). Only the initial stages of the reaction are documented in the results obtained within this work. The following steps are hypothetic. On the basis of the highest TOF obtained on $\mathrm{CuAu}$ / $\mathrm{ZrO}_{2}$ which contained only metallic gold and almost exclusively 

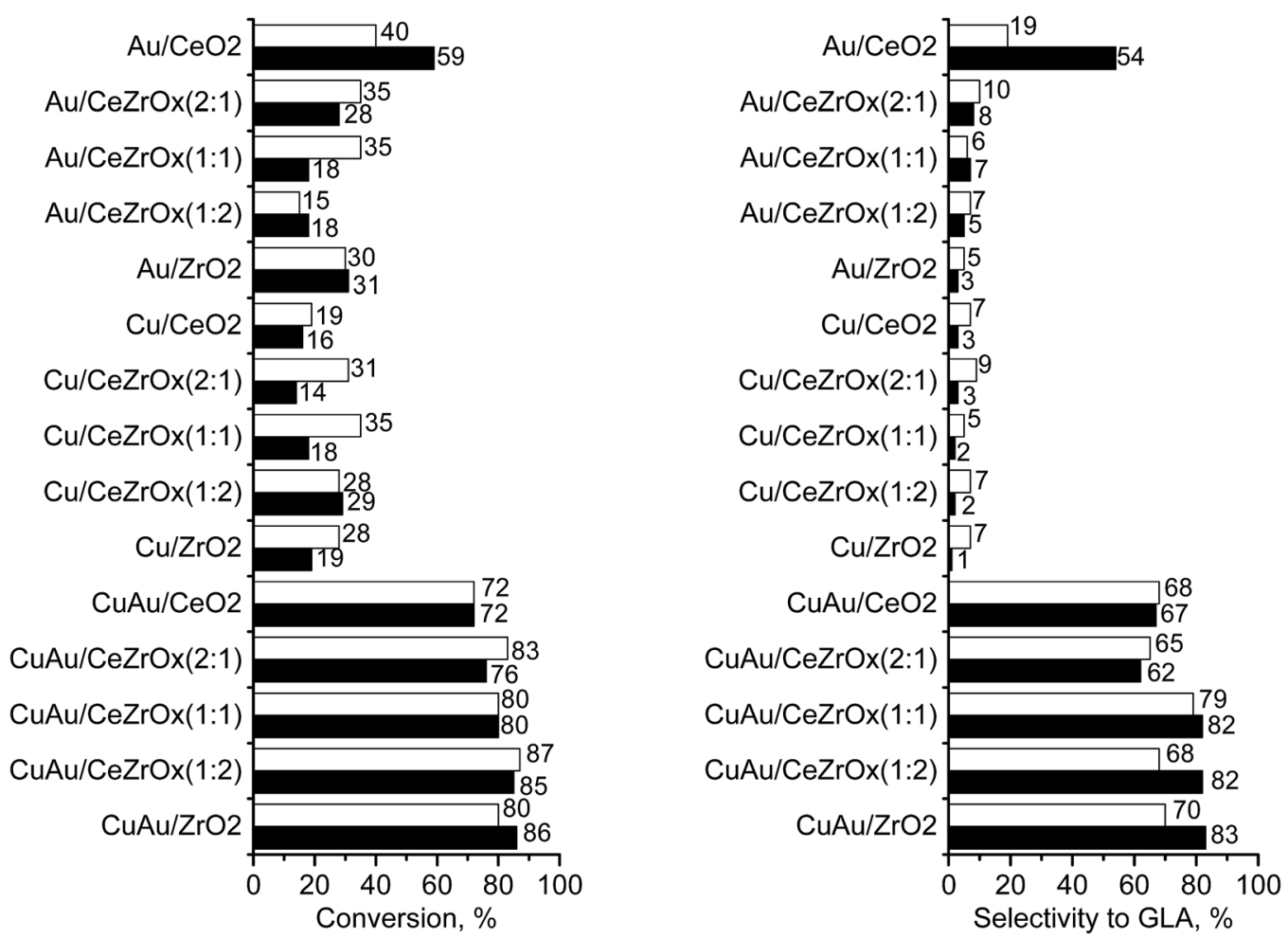

Fig. 6 Glycerol conversion (left side) and selectivity to glyceric acid (GLA) (right side) in the oxidation under stirring speed of 1000 rpm in the $1^{\text {st }}$ (white bars) and the $2^{\text {nd }}$ (black bars) cycle of the reaction performed at $333 \mathrm{~K}$ for $5 \mathrm{~h}$.

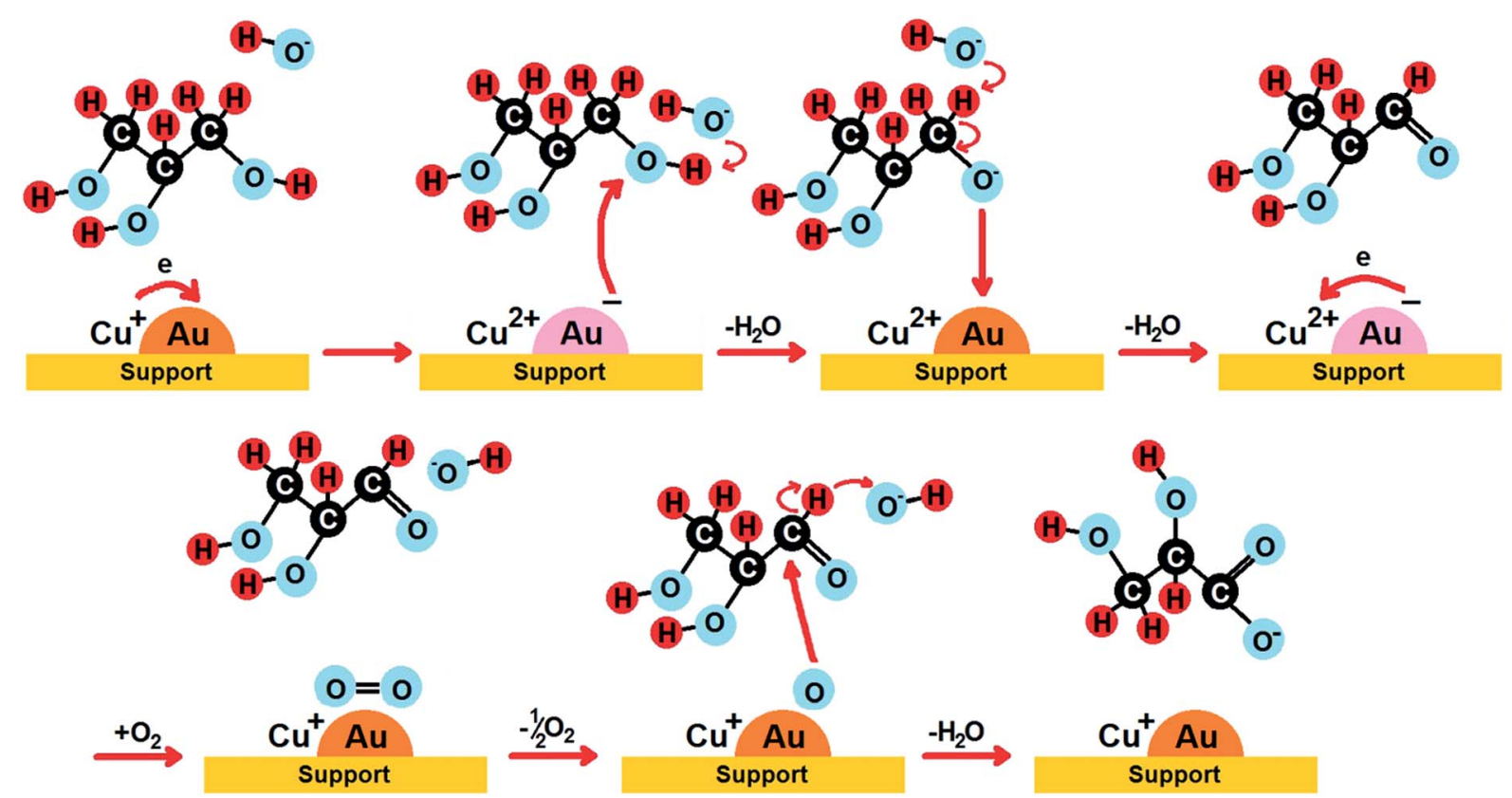

Scheme 2 Proposed scheme for the formation of glyceric acid on bimetallic catalysts supported on cerium and zirconium oxides.

$\mathrm{Cu}^{+}$cations, $\mathrm{Au}^{0}$ particles and $\mathrm{Cu}^{+}$are proposed as active centres at the beginning of the reaction.

In the proposed reaction cycle the different surface gold and copper species are involved. Moreover, the role of the hydroxyl groups from the reaction medium are pointed out.
Hydroxide anions from sodium hydroxide initiate the dehydrogenation via $\mathrm{H}$-abstraction of one of the primary $\mathrm{OH}$ groups of glycerol according to the literature data. ${ }^{33}$ This is enhanced by the interaction of negative charge on gold formed by an electron transfer from $\mathrm{Cu}^{+}$species. The 
following electron transfers from the aldehyde ion to $\mathrm{Au}^{0}$ and from gold containing negative charge to $\mathrm{Cu}^{2+}$ result in the rebuilding the primary metal species on the surface. In the next step oxygen is dissociatively chemisorbed on metallic gold particle, hydrogen from aldehyde group is abstracted by hydroxyls from the reaction medium and glyceric acid ion is formed. Scheme 2 indicates the crucial role of the electron transfer between the following pairs of copper and gold species: (i) $\mathrm{Cu}^{+}$and $\mathrm{Au}^{0}$ or (ii) $\mathrm{Cu}^{2+}$ and $\mathrm{Au}^{-}$. The catalysts exhibiting the highest TOF values, i.e. $\mathrm{CuAu} / \mathrm{ZrO}_{2}(\mathrm{TOF}=1236$ $\left.\mathrm{h}^{-1}\right)$ and $\mathrm{CuAu} / \mathrm{CeZrO}_{x}(1: 2)\left(\mathrm{TOF}=901 \mathrm{~h}^{-1}\right)$, contain the highest amount of $\mathrm{Cu}^{+}(86 \%)-\mathrm{Au}^{0}(100 \%)$ and $\mathrm{Cu}^{2+}(66 \%)-$ $\mathrm{Au}^{-}(67 \%)$, respectively. In the other bimetallic catalysts the dominant species of copper and gold are $\mathrm{Cu}^{+}$and $\mathrm{Au}^{0}$ (Table 4) between which the electron transfer does not occur. Such catalysts reveal lower TOF values.

\section{Conclusions}

All catalysts obtained within this work were mesoporous oxides containing also micropores and the microporosity increases with increasing zirconium content in the supports. It was evidenced the presence of gold species in the metallic form $\mathrm{Au}^{0}$, cationic $\mathrm{Au}^{\delta+}$ and negatively charged gold, the latter only in bimetallic copper-gold, catalysts. Moreover, the presence of cationic copper species, $\mathrm{Cu}^{+}$and $\mathrm{Cu}^{2+}$ were evidenced. The interaction between all the components of the catalysts was evidenced and its role in the initial step of the catalytic oxidation of glycerol was discussed.

Bimetallic gold-copper catalysts were significantly more active in glycerol oxidation than the respective monometallic samples and they were highly selective to glyceric acid. High gold dispersion in bimetallic catalysts was supposed to be responsible for high glycerol conversion but negative charge on gold seemed to enhance the activity. $\mathrm{Cu}^{+}$species played an important role in the achievement of high selectivity to glyceric acid. The bimetallic catalysts were chemically stable. They were proved to be active in reuse and to show higher selectivity to glyceric acid than in the first run.

On the basis of the characterization of the catalysts and the results of glycerol oxidation, one can postulate that metallic gold was the active phase in the oxidation of glycerol, whereas copper species drive the selectivity of the reaction. The presence of copper also increased the rate of the first reaction step, i.e. the $\mathrm{H}$-abstraction from glycerol molecules. Moreover, gold interacted with copper located in vicinity by electron transfer from $\mathrm{Cu}^{+}$to metallic gold or from $\mathrm{Au}^{-}$to $\mathrm{Cu}^{2+}$. The electron transfer between the aforementioned metal species is crucial in the reaction steps of glycerol oxidation (Scheme 2). Therefore, for high reaction rate the high content of above indicated pairs of metal species $\left(\mathrm{Cu}^{+}-\mathrm{Au}^{0}\right.$ and $\left.\mathrm{Cu}^{2+}-\mathrm{Au}^{-}\right)$is required. The interaction of gold and copper species with the supports also influenced the types of metallic species formed and therefore the chemical composition of the supports played an important role in the catalytic activity and selectivity.

\section{Acknowledgements}

We acknowledge the National Science Centre in Poland for the financial support (project No. 2014/13/N/ST5/01282) and P. K. is thankful for the financial support of the Scientific Exchange Programme Sciex-NMS Ch (project No. 12.258). We are much grateful to Dr Frank Krumeich and the Electron Microscopy Centre of ETH Zürich (EMEZ) for the STEM-EDXS measurements.

\section{References}

1 A. Aguirre, C. E. Barrios, A. Aguilar-Tapia, R. Zanella, M. A. Baltanás and S. E. Collins, Top. Catal., 2016, 59, 347356.

2 N. Sasirekha, P. Sangeetha and Y.-W. Chen, J. Phys. Chem. C, 2014, 118, 15226-15233.

3 Y. Iizuka, T. Miyamae, T. Miura, M. Okumura, M. Date and M. Haruta, J. Catal., 2009, 262, 280-286.

4 X. Liu, A. Wang, T. Zhang, D. S. Su and C. Y. Mou, Catal. Today, 2011, 160, 103-108.

5 X. Liu, A. Wang, L. Li, T. Zhang, C.-Y. Mou and J.-F. Lee, J. Catal., 2011, 278, 288-296.

6 A. Penkova, K. Chakarova, O. H. Laguna, K. Hadjiivanov, F. Romero Saria, M. A. Centeno and J. A. Odriozola, Catal. Commun., 2009, 10, 1196-1202.

7 T. Déronzier, F. Morfin, M. Lomello and J.-L. Rousset, J. Catal., 2014, 311, 221-229.

8 S. Rousseau, O. Marie, P. Bazin, M. Daturi, S. Verdier and V. Harle, J. Am. Chem. Soc., 2010, 132(31), 10832-10841.

9 J. C. Colmenares, P. Lisowski, D. Łomot, O. Chernyayeva and D. Lisovytskiy, ChemSusChem, 2015, 8, 1676-1685.

10 I. Sobczak and E. Dembowiak, J. Mol. Catal. A: Chem., 2015, 409, 137-148.

11 P. Kaminski and M. Ziolek, J. Catal., 2014, 312, 249-262.

12 I. Sobczak and Ł. Wolski, Catal. Today, 2015, 254, 72-82.

13 W. C. Ketchie, M. Murayama and R. J. Davis, J. Catal., 2007, 250, 264-273.

14 A. A. Rodriguez, C. T. Williams and J. R. Monnier, Appl. Catal., A, 2014, 475, 161-168.

15 L. E. Chinchilla, C. M. Olmos, A. Villa, A. Carlsson, L. Prati, X. Chen, G. Blanco, J. J. Calvino and A. B. Hungria, Catal. Today, 2015, 253, 178-189.

16 A. Villa, N. Dimitratos, C. E. Chan-Thaw, C. Hammond, L. Prati and G. J. Hutchings, Acc. Chem. Res., 2015, 48, 1403-1412.

17 H. Wang, C. Wang, H. Yan, H. Yi and J. Lu, J. Catal., 2015, 324, 59-68.

18 G. J. Hutchings, Catal. Today, 2014, 238, 69-73.

19 Z. Zhao, J. Arentz, L. A. Pretzer, P. Limpornpipat, J. M. Clomburg, R. Gonzalez, N. M. Schweitzer, T. Wu, J. T. Miller and M. S. Wong, Chem. Sci., 2014, 5, 3715-3728. 20 R. Fiorenza, C. Crisafulli, G. G. Condorelli, F. Lupo and S. Scirè, Catal. Lett., 2015, 145, 1691-1702.

21 P. Kaminski, I. Sobczak, P. Decyk, M. Ziolek, W. J. Roth, B. Campo and M. Daturi, J. Phys. Chem. C, 2013, 117, 2147-2159. 
22 P. Kaminski, M. Ziolek, B. Campo and M. Daturi, Catal. Today, 2015, 243, 218-227.

23 P. Kaminski and M. Ziolek, Appl. Catal., B, 2016, 187, 328341.

24 M. Ozawa, M. Kimura and A. Isogai, J. Alloys Compd., 1993, 193, 73-75.

25 A. Trovarelli and P. Fornasiero, Catalysis by ceria and related materials, ed. G. J. Hutchings, Imperial College Press, London, 2013, vol. 12, pp. 15-32.

26 M. Pijolat, M. Prin, M. Soustelle, O. Touret and P. Nortier, J. Chem. Soc., Faraday Trans., 1995, 91, 3941-3948.

27 E. G. Rodrigues, M. F. R. Pereira, J. J. Delgado, X. Chen and J. J. M. Órfão, Catal. Commun., 2011, 16, 64-69.

28 A. Villa, A. Gaiassi, I. Rossetti, C. L. Bianchi, K. van Benthem, G. M. Veith and L. Prati, J. Catal., 2010, 275, 108-116.

29 S.-S. Liu, K.-Q. Sun and B.-Q. Xu, ACS Catal., 2014, 4, 22262230.

30 W. C. Ketchie, M. Murayama and R. J. Davis, Top. Catal., 2007, 44, 307-317.

31 Y. Zheng, X. Chen and Y. Shen, Chem. Rev., 2008, 108, 52535277.

32 S. A. Kondrat, P. J. Miedziak, M. Douthwaite, G. L. Brett, T. E. Davies, D. J. Morgan, J. K. Edwards, D. W. Knight, C. J. Kiely, S. H. Taylor and G. J. Hutching, ChemSusChem, 2014, 7, 1326-1334.

33 S. Carrettin, P. McMorn, P. Johnston, K. Griffin, C. J. Kiely and G. J. Hutchings, Phys. Chem. Chem. Phys., 2003, 5, 1329-1336.

34 E. Skrzyńska, J. Ftouni, A.-S. Mamede, A. Addad, M. Trentesaux, J.-S. Girardon, M. Capron, F. Dumeignil, et al., J. Mol. Catal. A: Chem., 2014, 382, 71-78.

35 L. Prati, P. Spontoni and A. Gaiassi, Top. Catal., 2009, 52, 288-296.

36 M. Hosseini, S. Siffert, R. Cousin, A. Aboukaïs, Z. Hadj-Sadok and B.-L. Su, C. R. Chim., 2009, 12, 654-659.

37 H. L. Tidahy, S. Siffert, J.-F. Lamonier, E. A. Zhilinskaya, A. Aboukaïs, Z.-Y. Yuan, A. Vantomme, B.-L. Su, X. Canet, G. De Weireld, M. Frère, T. B. N'Guyen, J.-M. Giraudon and G. Leclercq, Appl. Catal., A, 2006, 310, 61-69.

38 V. Idakiev, T. Tabakova, A. Naydenov, Z.-Y. Yuan and B.-L. Su, Appl. Catal., B, 2006, 63, 178-186.

39 D. Andreeva, L. Ilieva, V. Idakiev, J. L. Blin, L. Gigot and B.-L. Su, Appl. Catal., A, 2003, 243, 25-39.

40 E. Smolentseva, A. Simakov, S. Beloshapkin, M. Estrada, E. Vargas, V. Sobolev, R. Kenzhin and S. Fuentes, Appl. Catal., B, 2012, 115-116, 117-128.

41 R. Zanella, S. Giorgio, C. R. Henry and C. Louis, J. Phys. Chem. B, 2002, 106, 7634-7642.

42 R. Zanella, L. Delannoy and C. Louis, Appl. Catal., A, 2005, 291, 62-72.

43 M. Yashima and T. Wakita, Appl. Phys. Lett., 2009, 94, 171902.

44 L. F. Liotta, G. Pantaleo, F. Puleo and A. M. Venezia, Catal. Today, 2012, 187, 10-19.

45 A.-Q. Wang, Y.-P. Hsieh, Y.-F. Chen and C.-Y. Mou, J. Catal., 2006, 237, 197-206.
46 A.-Q. Wang, J.-H. Liu, S.-D. Lin, T.-S. Lin and C.-Y. Mou, J. Catal., 2005, 233, 186-197.

47 L. Escamilla-Perea, R. Nava, B. Pawelec, M. G. Rosmaninho, C.-L. Peza-Ledesma and J. L. G. Fierro, Appl. Catal., A, 2010, 381, 42-53.

48 L. F. Chen, X. L. Zhou, L. E. Norena, J. A. Wang, J. Navarrete, P. Salas, A. Montoya and P. Del Angel, J. Solid State Chem., 2007, 180, 2958-2972.

49 E. Rodriguez-Castellon, A. Jimenez-Lopez, P. MarirelesTorres, D. J. Jones, J. Roziere, M. Trombetta, G. Busca, M. Lenarda and L. Storaro, J. Solid State Chem., 2003, 175, 159-169.

50 J. Goscianska, M. Ziolek, E. Gibson and M. Daturi, Catal. Today, 2010, 152, 33-41.

51 Metal Nanoparticles. Synthesis, Characterization and Applications, ed. D. L. Feldheim and C. A. Foss, B. M. Dekker, Inc., New York, 2002.

52 I. Tuzovskaya, N. Bogdanchikova, A. Simakov, V. Gurin, A. Pestryakov, M. Avalos and M. H. Farias, Chem. Phys., 2007, 338, 23-32.

53 S. Velu, K. Suzuki, M. Okazaki, M. P. Kapoor, T. Osaki and F. J. Ohashi, J. Catal., 2000, 194, 373-384.

54 A. Kong, H. Wang, X. Yang, Y. Hou and Y. Shan, Microporous Mesoporous Mater., 2009, 118, 348-353.

55 C. M. Chanquia, K. Sapag, E. Rodriguez-Castellon, E. R. Herrero and G. A. J. Eimer, J. Phys. Chem. C, 2010, 114, 1481-1490.

56 G. Águila, F. Gracia, J. Cortés and P. Araya, Appl. Catal., B, 2008, 77, 325-338.

57 H. Praliaud, S. Mikhailenko, Z. Chajar and M. Primet, Appl. Catal., B, 1998, 16, 359-374.

58 F.-W. Chang, H.-Y. Yu, L. S. Roselin, H.-C. Yang and T.-C. Ou, Appl. Catal., A, 2006, 302, 157-167.

59 N. Bogdanchikova, A. Pestryakov, I. Tuzovskaya, T. A. Zepeda, M. H. Farias, H. Tiznado and O. Martynyuk, Fuel, 2013, 110, 40-47.

60 J. Hua, K. Wie, Q. Zheng and Z. Lin, Appl. Catal., A, 2004, 259, 121-130.

61 A. Zwijnenburg, A. Goosens, W. G. Sloof, M. W. J. Graje, A. M. Kraan, L. J. Jongth, M. Makee and J. A. Moulijn, J. Phys. Chem. B, 2002, 106, 9853-9862.

62 N. Dimitratos, A. Villa, C. L. Bianchi, L. Prati and M. Makkee, Appl. Catal., A, 2006, 311, 185-192.

63 S. Albonetti, T. Pasini, A. Lolli, M. Blosi, M. Piccinini, N. Dimitratos, J. A. Lopez-Sanchez, D. J. Morgan, A. F. Carley, G. J. Hutchings and F. Cavani, Catal. Today, 2012, 195, 120-126.

64 J. Xu, T. White, P. Li, C. He, J. Yu, W. Yuan and Y.-F. Han, J. Am. Chem. Soc., 2010, 132, 10398-10406.

65 O. A. Simakova, E. Smolentseva, M. Estrada, E. V. Murzina, S. Beloshapkin, S. M. Willför, A. V. Simakov and D. Y. Murzin, J. Catal., 2012, 291, 95-103.

66 R. J. Chimentão, F. Medina, J. L. G. Fierro, J. Llorca, J. E. Sueiras, Y. Cesteros and P. Salagre, J. Mol. Catal. A: Chem., 2007, 274, 159-168. 
67 J. Liorca, M. Domínguez, C. Ledesma, R. J. Chimentão, F. Medina, J. Sueiras, I. Angurell, M. Seco and O. Rossell, J. Catal., 2008, 258, 187-198.

68 A. Gupta, U. V. Waghmare and M. S. Hegde, Chem. Mater., 2010, 22, 5184-5198.

69 L. H. Reddy, G. K. Reddy, D. Devaiah and B. M. Reddy, Appl. Catal., A, 2012, 445-446, 297-305.

70 G. Fierro, M. L. Jacono, M. Inversi, P. Porta, R. Lavecchia and F. Cioci, J. Catal., 1994, 148, 709-721.

71 O. V. Komova, A. V. Simakov, V. A Rogov, D. I. Kochubei, G. V. Odegova, V. V. Kriventsov, E. A. Paukshtis, V. A. Ushakov, N. N. Sazonova and T. A. Nikoro, J. Mol. Catal. A: Chem., 2000, 161, 191-204.

72 F. Boccuzzi, A. Chiorino, G. Martra, M. Gargano, N. Ravasio and B. Carrozziniz, J. Catal., 1997, 165, 129-139.

73 B. Thirupathi and P. G. Smirniotis, Appl. Catal., B, 2011, 110, 195-206.

74 S. Scire, P. M. Riccobene and C. Crisafulli, Appl. Catal., B, 2010, 101, 109-117.

75 T. Tabakova, F. Boccuzzi, M. Manzoli, J. W. Sobczak, V. Idakiev and A. Andreeva, Appl. Catal., A, 2006, 298, 127-143.

76 G. Avgouropoulos and T. Ioannides, Appl. Catal., A, 2003, 244, 155-167.

77 L. J. Kundakovic and M. Flytzani-Stephanopoulos, Appl. Catal., A, 1998, 171, 13-29.
78 W. Liu and M. Flytzani-Stephanopoulos, Chem. Eng. J., 1996, 64, 283-294.

79 X. Jiang, G. Lu, R. Zhou, J. Mao, Y. Chen and X. Zheng, Appl. Surf. Sci., 2001, 173, 208-220.

80 J. B. Wang, S.-C. Lin and T.-J. Huang, Appl. Catal., A, 2002, 232, 107-120.

81 S. Zhang, W. Huang, X. Qiu, B. Li, X. Zheng and S. Wu, Catal. Lett., 2002, 80, 41-46.

82 M.-F. Luo, Y.-J. Zhong, X.-X. Yuan and X.-M. Zheng, Appl. Catal., A, 1997, 162, 121-131.

83 A. Gupta, U. V. Waghmare and M. S. Hegde, Chem. Mater., 2010, 22, 5184-5198.

84 S. Demirel, P. Kern, M. Lucas and P. Claus, Catal. Today, 2007, 122, 292-300.

85 A. Villa, G. M. Veith and L. Prati, Angew. Chem., Int. Ed., 2010, 49, 4499-4502.

86 A. Behr, J. Eilting, K. Irawadi, J. Leschinski and F. Linder, Green Chem., 2008, 10, 13-30.

87 W. C. Ketchie, Y.-L. Fang, M. S. Wong, M. Murayama and R. J. Davis, J. Catal., 2007, 250, 94-101.

88 Y. Zheng, X. Chen and Y. Shen, Chem. Rev., 2008, 108, 52535277.

89 A. Villa, G. M. Veith, D. Ferri, A. Weidenkaff, K. A. Perry, S. Campisi and L. Prati, Catal. Sci. Technol., 2013, 3, 394-399.

90 A. Villa, D. Wang, G. M. Veith, F. Vindignid and L. Prati, Catal. Sci. Technol., 2013, 3, 3036-3041. 